\title{
Proteomic study of the brackish water mussel Mytilopsis leucophaeata
}

\author{
Feico MAH Schuurmans Stekhoven ${ }^{1 *}$, Gerard van der Velde ${ }^{1,4}$, Tsung-Han Lee ${ }^{2}$ and Andrew R Bottrill ${ }^{3}$
}

\begin{abstract}
Background: We encountered the opportunity to study proteochemically a brackish water invertebrate animal, Mytilopsis leucophaeata, belonging to the bivalves which stem from the second half of the Cambrian Period (about 510 million years ago). This way, we were able to compare it with the vertebrate animal, the frilled shark (Chlamydoselachus anguineus) that stems from a much later period of geologic time (Permian: 245-286 MYA).

Results: The mussel contains a well-adapted system of protein synthesis on the ER, protein folding on the ER, protein trafficking via COPI or clathrin-coated vesicles from endoplasmic reticulum (ER) to Golgi and plasmalemma, an equally well-developed system of actin filaments that with myosin forms the transport system for vesicular proteins and tubulin, which is also involved in ATP-driven vesicular protein transport via microtubules or transport of chromosomes in mitosis and meiosis. A few of the systems that we could not detect in M. leucophaeata in comparison with $C$. anguineus are the synaptic vesicle cycle components as synaptobrevin, cellubrevin ( $v$-snare) and synaptosomal associated protein 25-A (t-snare), although one component: Ras-related protein (O-Rab1) could be involved in synaptic vesicle traffic. Another component that we did not find in M. leucophaeata was Rab11 that is involved in the tubulovesicular recycling process of $\mathrm{H}^{+} / \mathrm{K}^{+}$-ATPase in $\mathrm{C}$. anguineus. We have not been able to trace the $\mathrm{H}^{+} / \mathrm{K}^{+}$-ATPase of $\mathrm{M}$. leucophaeata, but $\mathrm{Na}^{+} / \mathrm{K}^{+}$-ATPase was present. Furthermore, we have studied the increase of percent protein expression between 1,070 MYA (the generation of the Amoeba Dictyostelium discoideum) and present (the generation of the mammal Sus scrofa= wild boar). In this time span, three proteomic uprises did occur: 600 to 500 MYA, 47.5 to $4.75 \mathrm{MYA}$, and 1.4 to 0 MYA. The first uprise covers the generation of bivalves, the second covers gold fish, chicken, brine shrimp, house mouse, rabbit, Japanese medaka and Rattus norvegicus, and the third covers cow, chimpanzee, Homo sapiens, dog, goat, Puccinia graminis and wild boar. We hypothesise that the latter two uprises are related to geological and climate changes and their compensation in protein function expression.
\end{abstract}

Conclusions: The proteomic and evolutionary data demonstrate that M. leucophaeata is a highly educatioanal animal to study.

Keywords: Mytilopsis leucophaeata; Proteomics; Localisation; Function and adaptation periods

\section{Background}

Mytilopsis leucophaeata or the brackish water mussel, belonging to the Dreissenidae or bivalve mussels, originated from Europe more than 60 million years ago (Paleocene, Verween et al. 2010). Subsequently, it disappeared to Central America and returned to Europe (harbour of Antwerp) in 1835. Since then, it is a stable inhabitant of European brackish waters.

\footnotetext{
* Correspondence: F.Stekhoven@gmail.com

'Department of Animal Ecology and Ecophysiology, Faculty of Science, Radboud University Nijmegen, Heyendaalseweg 135, 6525 AJ Nijmegen, The Netherlands

Full list of author information is available at the end of the article
}

In the period of September 2009 to September 2010, two of my colleagues studied the influence of a number of parameters (depth, temperature, salinity and illumination) on size, growth condition, diet and attachment via development of byssal threads (Grutters and Verhofstad 2010). Bivalves have survived a long history from about 510 million years ago to present. This means that it has been adapted to geologically and climate-changing conditions, which might be reflected in the evolution of their proteome. For this reason, the present study was started in order to see whether the presence of certain proteins might unveil certain metabolic systems in this aquatic animal. Almost simultaneously, an article from

\section{它 Springer}


Riva et al. (2012) did so in relation to the effect of a pollutant (triclosan) on the metabolism of Dreissena polymorpha with emphasis on gills. In the same year, Fields et al. (2012) and Tomanek et al. (2012) published a study on the effect of temperature and hyposalinity on protein expression in the gills of the Mytilidae Mytilus galloprovincialis and Mytilus trossulus. In addition, we were interested in comparing amino acid sequences of our mussel with animals stemming from later periods of life in order to cheque the phylogenetic developments that had taken place meanwhile.

\section{Methods}

Forty individuals of the brackish water mussel, caught from a branch of the North Sea Channel to Amsterdam harbour, were taken by scalpel knives and tweezers from their shells, yielding a total wet weight of $1.8 \mathrm{~g}$, sufficient for further analysis. The body parts were taken up in $5 \mathrm{ml}$ triethanolamine $\mathrm{HCl}, \mathrm{pH} 7.0$ in $25 \%$ glycerol in the presence of $0.5 \mathrm{mM}$ phenylmethylsulfonyl fluoride (PMSF) to prevent autolysis (Schuurmans Stekhoven et al. 2003). Further procedures, such as Potter-Elvehjem homogenisation; fractionated centrifugation to fractions F1, F2 and F3; delipidation of fractions prior to electrophoresis; electrophoretic separation of proteins in the fractions; staining and destaining of the gels; determination of the apparent molecular weights of the protein bands on gel; excision of the protein bands; transport to the mass spectrometric analysis laboratory in Leicester; as well as the mass spectrometric analysis itself, is given in full detail in our previous publication (Schuurmans Stekhoven et al. 2010).

Information as to the cellular localisation and function of the analysed proteins stem from handbooks like Biochemistry of Hubert Stryer, Google (Scholar), Pubmed. com, BLAST and UniProtKB/Swiss-Prot Protein Knowledgebase and literature referred to therein. The absorption spectrum of the brownish coloured F1 fraction (325 to $750 \mathrm{~nm}$ ) was made with a Zeiss M4QIII spectrophotometer at 20- to 50-nm intervals. A $100 \mu \mathrm{l}$ of the F1 fraction was dissolved in $1 \mathrm{ml} 2 \%$ SDS, subsequently centrifuged for $5 \mathrm{~min}$ at $5,000 \mathrm{rpm}$ in a table top centrifuge, and the supernatant scanned.

\section{Results}

\section{Homogenisation and fractional centrifugation}

Potter-Elvehjem homogenisation of the mussels required very harsh and frequent pottering, yielding a brownish homogenate. Subsequent centrifugation at 1,200, 9,000, and $100,000 \mathrm{~g}$ yielded the F1 to F3 fractions. Total protein (mg) of the fractions amounted to 78.3 for F1, 7.03 for F2 and 6.2 for F3, hence ratio F1:F2; F3 = 12.6:1.13:1.0. This ratio brought about association with the kidney (21.5:11.2:1.0) and colon (19.4:3.9:1.0) of the frilled shark Chlamydoselachus anguineus (Schuurmans Stekhoven et al.
2012) in which particular proteins (L-plastin, moesin, filamin $\mathrm{A}$ and $\alpha$-actinin) are serving as additional construct in linking filaments (microtubules) to the plasma membrane. However, in the mussel case, in particular in relation to the brown colour of F1, and less so of F2, we had to think more in terms of byssal threads, the biopolymers by which mussels attach themselves to their substrate like rocks or even ship walls. The brown colour is based on an aqueous solution of pheomelanin (Napolitano et al. 2008) of which the almost exponential absorption curve (down to $325 \mathrm{~nm}$ ) fits to our curve of M. leucophaeata F1 (Figure 1). Byssal threads apparently are high MW biopolymers as F1 did not demonstrate any entrance of protein into the gel. This started only in the lightly brown F2 and came to full expression by the light yellow F3, which demonstrated proteins in the apparent molecular weight range of 14.1 to $240 \mathrm{kDa}$ (Tables 1, 2, 3 and 4). The tables are subdivided into prokaryotic and eucaryotic ribosomal subunits (Table 1), proteins from the ER, Golgi network and plasma membrane (Table 2), proteins of the cytoskeleton and muscle (Table 3) and cellular vacuoles, vaults, nuclei and mitochondria (Table 4). From all these proteins, the prokaryotic or eucaryotic origin is mentioned as well as the function and cellular localisation as could be found in literature, including data banks. All proteins are accompanied by their accession numbers from [UniProtKB/SwissProt] between square brackets. Confusion between capital $\mathrm{O}$ and the number zero is excluded since capital $\mathrm{O}$ is only present at the first position and number zero in any position from 2 to 6 of the accession series. Translation of the accession data to protein easily occurs by using the programme PubMed (www.ncbi.nlm. nih.gov/pubmed) by choosing the term protein.

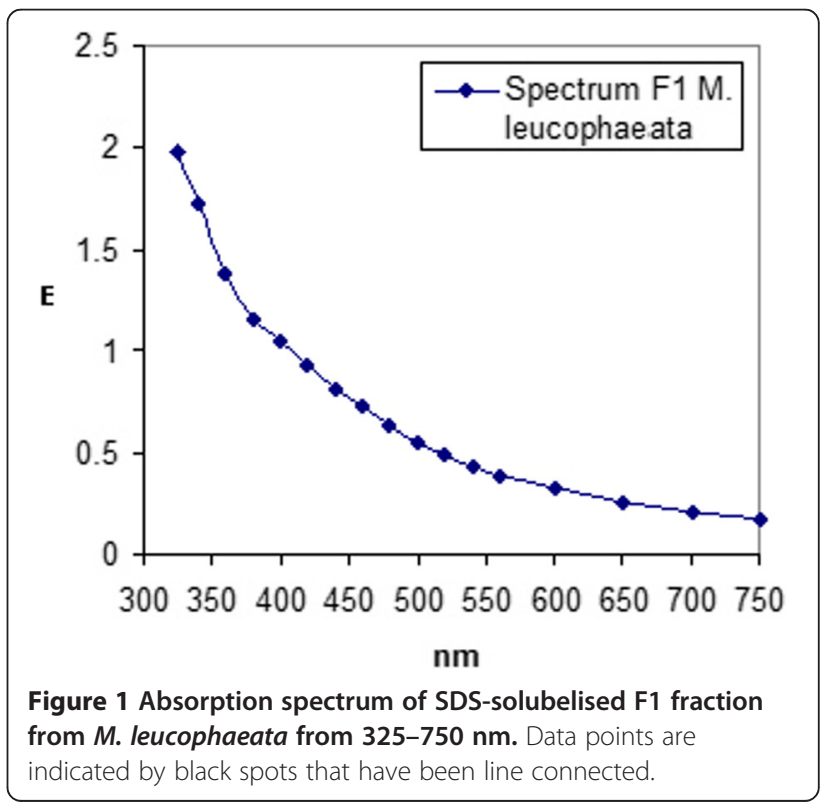


Table 1 Ribosomal composition of the F3 fraction (14.1 to $240 \mathrm{kDa}$ ) of $M$. leucophaeata in the prokaryotic and eucaryotic range

\begin{tabular}{|c|c|c|c|}
\hline Ribosomal subunit & Pro-/eucaryote & Function & Localisation \\
\hline 30S-S1 [Q9HZ71] & Pseudomonas aeruginosa PAO1 & Protein synthesis & Protoplasma \\
\hline 30S-S2 [C3K5E6] & Pseudomonas fluorescens SBW25 & Idem & Idem \\
\hline 30S-S3 [Q3K5Z4] & Pseudomonas fluorescens PfO-1 & Idem & Idem \\
\hline 30S-S4 [Q3K611] & Pseudomonas fluorescens PfO-1 & Idem & Idem \\
\hline 30S-S5 [C3K2V9] & Pseudomonas fluorescens SBW25 & Idem & Idem \\
\hline 30S-S6 [A4XPZ7] & Pseudomonas mendocina ymp & Idem & Idem \\
\hline 30S-S7 [C3K2Y0] & Pseudomonas fluorescens SBW25 & Idem & Idem \\
\hline 30S-S7 [A1AGM8] & Escherichia coli APEC O1 & Idem & Idem \\
\hline 30S-S8 [A4VHP4] & Pseudomonas stutzeri A1501 & Idem & Idem \\
\hline 30S-S9 [C3K6E2] & Pseudomonas fluorescens SBW25 & Idem & Idem \\
\hline 30S-S10 [A4VHM9] & Pseudomonas stutzeri A1501 & Idem & Idem \\
\hline 30S-S11 [A4VHQ3] & Pseudomonas stutzeri A1501 & Idem & Idem \\
\hline 30S-S13 [C3K2V4] & Pseudomonas fluorescens SBW25 & Idem & Idem \\
\hline 30S-S14 [Q48D49] & Pseudomonas syringae pv. phaseolicola 1448A & Idem & Idem \\
\hline 50S-L1 [C3K246] & Pseudomonas fluorescens SBW25 & Idem & Idem \\
\hline 50S-L1 [Q889Y1] & Pseudomonas syringae pv. tomato str. DC3000 & Idem & Idem \\
\hline 50S-L2 [C3K2X3] & Pseudomonas fluorescens SBW25 & Idem & Idem \\
\hline 50S-L3 [C3K2X6] & Pseudomonas fluorescens SBW25 & Idem & Idem \\
\hline 50S-L4 [C3K2X5] & Pseudomonas fluorescens SBW25 & Idem & Idem \\
\hline 50S-L5 [C3K2W4] & Pseudomonas fluorescens SBW25 & Idem & Idem \\
\hline 50S-L6 [B1JAJ7] & Pseudomonas putida W619 & Idem & Idem \\
\hline 50S-L9 [C3KE70] & Pseudomonas fluorescens SBW25 & Idem & Idem \\
\hline 50S-L9 [A1AJA7] & Escherichia coli APEC O1 & Idem & Idem \\
\hline 50S-L10 [C3K2Y5] & Pseudomonas fluorescens SBW25 & Idem & Idem \\
\hline 50S-L11 [C3K2Y7] & Pseudomonas fluorescens SBW25 & Idem & Idem \\
\hline 50S-L13 [C3K6E1] & Pseudomonas fluorescens SBW25 & Idem & Idem \\
\hline 50S-L14 [A4VHP0] & Pseudomonas stutzeri A1501 & Idem & Idem \\
\hline 50S-L15 [C3K2V7] & Pseudomonas fluorescens SBW25 & Idem & Idem \\
\hline 50S-L16 [C3K2W9] & Pseudomonas fluorescens SBW25 & Idem & Idem \\
\hline 50S-L17 [A4VHQ6] & Pseudomonas stutzeri A1501 & Idem & Idem \\
\hline 50S-L18 [C3K2W0] & Pseudomonas fluorescens SBW25 & Idem & Idem \\
\hline 50S-L19 [C3K1G8] & Pseudomonas fluorescens SBW25 & Idem & Idem \\
\hline 50S-L22 [A4XZ85] & Pseudomonas mendocina ymp & Idem & Idem \\
\hline 50S-L24 [C3K2W5] & Pseudomonas fluorescens SBW25 & Idem & Idem \\
\hline 50S-L25 [Q3K6W3] & Pseudomonas fluorescens Pf 0-1 & Idem & Idem \\
\hline 40S-SA [A3RLT6] & Pinctada fucata (pearl oyster) & Protein synthesis & ER \\
\hline 40S-SA [P38981] & Urechis caupo (spoon worm) & $\begin{array}{l}\text { Assembly and/or stabilisation } \\
\text { of the } 40 \text { S ribosomal subunit }\end{array}$ & $\begin{array}{l}\text { Localisation in adhesion } \\
\text { complexes (Willett et al. 2010) }\end{array}$ \\
\hline 40S-S2 [O18789] & Bos taurus (cattle) & Protein synthesis & ER \\
\hline 40S-S3 [P23396] & Homo sapiens (human) & Idem & Idem \\
\hline 40S-S3a [A7S3J7] & $\begin{array}{l}\text { Nematostella vectensis } \\
\text { (starlet sea anemone) }\end{array}$ & Idem & Idem \\
\hline 40S-S4 [Q4GXU6] & Carabus granulatus (beetle) & Idem & Idem \\
\hline 40S-S5 [P46782] & Homo sapiens (human) & Idem & Idem \\
\hline
\end{tabular}




\begin{tabular}{|c|c|c|c|}
\hline 40S-S6 [Q90YR8] & Ictalurus punctatus (channel catfish) & Idem & Idem \\
\hline 40S-S7 [A6H769] & Bos taurus (cow) & rRNA maturation & $\begin{array}{l}\text { Together with NEK6 } \\
\text { (serine/threonine kinase) } \\
\text { in centrosome (microtubule } \\
\text { organising centre, MTOC) }\end{array}$ \\
\hline 40S-S9 [A6QLG5] & Bos taurus (cow) & Protein synthesis & ER \\
\hline 40S-S13 [P49393] & Xenopus tropicalis (western clawed frog) & Idem & Idem \\
\hline 40S-S14 [P14130] & Drosophila melanogaster (fruit fly) & Idem & Idem \\
\hline 40S-S16 [P14131] & Mus musculus (house mouse) & Idem & Idem \\
\hline 40S-S17 [A5PK63] & Bos taurus (cattle) & Idem & Idem \\
\hline 40S-S18 [A5JST6] & Capra hircus (goat) & Idem & Idem \\
\hline 40S-S18 [Q8IT98] & Argopecten irradians (bay scallop) & Idem & Idem \\
\hline 40S-S19 [Q94613] & Mya arenaria (soft-shell clam) & Idem & Idem \\
\hline 40S-S24 [O42387] & Takifugu rubripes (tiger puffer) & Idem & Idem \\
\hline 40S-S26 [P27085] & Octopus vulgaris & Idem & Idem \\
\hline 40S-S27-like [P24051] & Rattus norvegicus (Norway rat) & Idem & Idem \\
\hline 60S-L4 [P50878] & Rattus norvegicus (Norway rat) & Idem & Idem \\
\hline 60S-L4-B [P02385] & Xenopus laevis (African clawed frog) & Idem & Idem \\
\hline 60S-L5 [P09895] & Rattus norvegicus (Norway rat) & Idem & Idem \\
\hline 60S-L5 [O76190] & Bombyx mori (silk worm) & Idem & Idem \\
\hline 60S-L7a [Q90YW2] & Ictalurus punctatus (channel catfish) & Idem & Idem \\
\hline 60S L7c[060143] & Schizosaccharomyces pombe 972 h- & Idem & Idem \\
\hline 60S-L8 [P41569] & Aedes albopictus (Asian tiger mosquito) & Idem & Idem \\
\hline 60S-L12 [E2RR58] & Canis lupus familiaris (dog) & Idem & Idem \\
\hline 60S-L16a [P26784] & Saccharomyces cerevisiae S288c (baker's yeast) & Idem & Idem \\
\hline 60S-L17 [AONGY0] & Anopheles gambiae (African malaria mosquito) & Idem & Idem \\
\hline 60S-L23a [P62750] & Homo sapiens (human) & Idem & Idem \\
\hline 60S-L26 [P12749] & Rattus norvegicus (Norway rat) & Idem & Idem \\
\hline
\end{tabular}

With names of the animals to whom the proteins are related + function and cellular localisation of these proteins.

Table 1 shows that $52 \%$ of the ribosomal subunits is of bacterial origin with a decreasing order in percentage for Pseudomonas fluorescens (32.8\%), Pseudomonas stutzeri (7.5\%), Pseudomonas mendocina (3\%), Pseudomonas syringae (3\%), Escherichia coli (3\%), Pseudomonas putida (1.5\%) and Pseudomonas aeruginosa (1.5\%). The other half of the components is occupied by eucaryotes, ranging from pearl oyster to Norway rat. Possible causes and impacts of the bacterial contamination will be handled under 'Discussion' section.

Outside Table 1, only very few bacterial proteins have been identified, except peptidoglycan-associated lipoprotein in the plasma membrane of P. putida (Table 2), outer membrane porin F from $P$. fluorescens (Table 2) and 2,3-bisphosphoglycerate-dependent phosphoglycerate mutase from Rhodospirillum centenum SW (Table 2). The latter photosynthetic bacterium is housing in marine and brackish water and so can be easily caught by the mussel valves. Still another intruder in the list of proteomics is ribulose bisphosphate carboxylase from Agrostis stolonifera (creeping bent grass) as this reaction takes place in chloroplasts. The habitat of creeping bent grass is on wetlands with tolerance to flooding (Garry Oak Ecosystems Recovery team: www.goert.ca/documents/A. stolonifera.pdf) or inundation of riparian zones which may have brought the plants in contact with the mussels.

Major intracellular activities, presented in Table 2, are protein folding on endoplasmic reticulum (ER) (endoplasmin, peptidyl-prolyl cis-trans isomerase $\mathrm{C}=$ cyclophilin C), assembly of multimeric protein complexes inside the ER (heat-shock $70 \mathrm{kDa}$ protein cognate $3,78 \mathrm{kDa}$ glucoseregulated protein) and protein translocon formation across the ER (dolichyl-diphosphooligosaccharide protein glycosyltransferase). In addition, we found a number of transport processes, such as cargo transport from transGolgi to plasma membrane (guanine nucleotide-binding 
Table 2 Proteins from ER, Golgi network and plasma membrane

\begin{tabular}{ll}
\hline Protein & Pro-/Eucaryot \\
\hline Endoplasmin [018750] & $\begin{array}{l}\text { Oryctolagus } \\
\text { cuniculus (rabbit) }\end{array}$ \\
$\begin{array}{l}\text { Guanine nucleotide-binding } \\
\text { protein subunit } \beta \text { [Q5GIS3] }\end{array}$ & $\begin{array}{l}\text { Pinctada fucata } \\
\text { (Japanese pear } \\
\text { oyster) }\end{array}$ \\
AP-1 complex, subunit & Mus musculus \\
$\beta-1$ [035643] & (mouse)
\end{tabular}

Clathrin heavy chain 1 [P11442] Rattus norvegicus

a-Amylase [P04745]

Glyceraldehyde-3-phosphate dehydrogenase 2 [Q9ESV6]

Transitional endoplasmic reticulum ATPase (TERA) [P03974]

Guanine nucleotide-binding protein G(o), subunit a [015976]

Idem $\mathrm{G}(\mathrm{q})$, subunit a [P38411]

Guanine nucleotide-binding protein subunit $\beta$-2-like 1, Rack1 $=$ receptor for activated $c$ kinase-1 [Q93134]

Peptidyl-prolyl cis-trans isomerase C (cyclophilin C) [Q08E11]

Actin, cytoplasmic 2 (from fibroblastic and epithelial cells) [A2BDB0]

ADP-ribosylation factor 1 (Arf 1) [P36579]

Peptidoglycan-associated lipoprotein [P0A138]

Sarcoplasmic/endoplasmic reticulum calcium ATPase 3 [Q9YGL9]

Outer membrane porin $\mathrm{F}$ [P37726]

Ribulose bisphosphate carboxylase large chain [A1EA16]

Glycogen phosphorylase from liver [P06737]

Homo sapiens (human)

Rattus norvegicus

Sus scrofa (wild boar)

Mizuhopecten

yessoensis (Yesso scallop)

Biomphalaria

Bos taurus (cow)

Xenopus laevis pombe $972 \mathrm{~h}$ -

Pseudomonas putida KT2440

Gallus gallus (chicken)

Pseudomonas fluorescens (creeping bent grass)

Homo sapiens (human)

\section{Function}

$\mathrm{Ca}^{2+}$-binding protein, possibly involved in

protein folding (Rowling et al. 1994)

Cargo transport from trans-Golgi network to plasma membrane

Subunit of adaptor protein complex-1, involved in protein sorting, mediating the recruitment of clathrin to the membrane and recognition of sorting signals within the cytoplasmic tails of transmembrane cargo molecules

Involved in cargo sorting (cf. adaptor protein complex-1 of Mus musculus)

Conversion of glyceraldehyde-3P to 1,3-bisphosphoglycerate; + Rab2 and protein kinase Ci driven tubulovesicular recycling of proteins from the Golgi to the ER (Tisdale et al. 2009)

Lymnaea stagnalis (great pond snail)

Involved in fragmentation of Golgi stacks during mitosis and reassembly after mitosis; further is TERA involved in the formation of tER (transitional ER) (UniProt KB/Swiss-Prot information)

Major neural signalling GTPase. Reacts on food deprivation (Hofler and Koelle 2011)

glabrata (blood fluke planorb = gastropod)

Involved in integrin signalling at adhesions, e.g. in a complex with kindlin-3

Cyclophilin is a protein folding catalyst

Probably involved in contractile ring

Schizosacharomyces

Protein trafficking via COPI or clathrin-coated vesicles from ER to Golgi and plasmalemma

Agrostis stolonifera

Presence in bivalves may be due to ingestion by the host (Wood 2011)

Involved in muscle contraction

Stabilisation of plasmalemma (multipass membrane protein)

Ribulose 1,5-bisphosphate $+\mathrm{CO}_{2}+\mathrm{H}_{2} \mathrm{O} \rightarrow 2$ 3-P-glycerate $+2 \mathrm{H}^{+}$, and 3-P-glycerate + 2-P-glycolate $\rightarrow$ ribulose 1,5-bisP $+\mathrm{O}_{2}$

Glycogen $(n)+P i \leftrightarrow g l u c o s e-1 P+\operatorname{glycogen}(n-1)$ (African clawed frog)

\section{Localisation}

ER

Golgi network and plasmalemma (Irannejad and Wedegaertner 2010)

Trans-Golgi network and/or clathrin-coated vesicles (UniProt KB/Swiss- Prot:O35643.2, cf. Robinson and Bonifacino 2001)

Clathrin-coated vesicles at the plasma membrane or trans-Golgi network

In oyster (Crassostrea gigas) preferentially in digestive tract (Huvet et al. 2003), RER, Golgi, cisternae, condensing vacuoles, and secretory granules (Geuze et al. 1979)

Vesicular tubular clusters

Golgi and ER

Plasmalemma (Feng et al. 2012)

ER (Wang and Heitman 2005)

Colocalisation with myosin $2 a$ in stress fibres and with VASP (vasodilator-stimulated phosphoprotein) in lamellipodia and focal adhesions (Dugina et al. 2009)

Cis/trans-Golgi and plasmalemma (Chavrier and Goud 1999; D'Souza-Schorey and Chavrier 2006)

Cell outer membrane

Localisation is in the name

Cell outer membrane (cf. VDAC in C. anguineus, Schuurmans Stekhoven et al. 2012)

Reactions take place in chloroplasts; presence in mollusks indicates contamination by plants
Microsomal fraction (ER or glycogen particles) (Tata 1964, Margolis et al. 1979) 
Table 2 Proteins from ER, Golgi network and plasma membrane (Continued)

\begin{tabular}{|c|c|c|c|}
\hline $\begin{array}{l}\text { Heat shock } 70 \text { kDa protein } \\
\text { [P08106] }\end{array}$ & $\begin{array}{l}\text { Gallus gallus } \\
\text { (chicken) }\end{array}$ & $\begin{array}{l}\text { Conservation of protein shape and anti-stress } \\
\text { protectant (De Maio 1999) }\end{array}$ & $\begin{array}{l}\text { Cytosol, plasma membrane and endosomes + } \\
\text { lysosomes (Nylandsted et al. 2004) }\end{array}$ \\
\hline $\begin{array}{l}\text { Heat shock } 70 \text { kDa protein } \\
\text { cognate } 3 \text { [P29844] }\end{array}$ & $\begin{array}{l}\text { Drosophila } \\
\text { melanogaster (fruit fly) }\end{array}$ & $\begin{array}{l}\text { Probably plays a role in facilitating the } \\
\text { assembly of multimeric protein complexes } \\
\text { inside the ER }\end{array}$ & $\begin{array}{l}\text { ER (for additional locations and } \\
\text { actions see above) }\end{array}$ \\
\hline $\begin{array}{l}78 \text { kDa glucose-regulated } \\
\text { protein [Q16956] }\end{array}$ & $\begin{array}{l}\text { Aplysia californica } \\
\text { (California sea hare } \\
=\text { mollusc) }\end{array}$ & $\begin{array}{l}\text { Belongs to the heat shock protein } 70 \text { family } \\
\text { with function as above }\end{array}$ & ER \\
\hline $\begin{array}{l}\text { Dolichyl-diphosphooligosaccharide- } \\
\text { protein glycosyltransferase subunit } \\
\text { STT3A [P46977] }\end{array}$ & $\begin{array}{l}\text { Homo sapiens } \\
\text { (human) }\end{array}$ & $\begin{array}{l}\text { Transfer of a high mannose oligosaccharide to } \\
\text { Asn-X-Ser/Thr in nascent polypeptide chains. } \\
\text { The complex associates with Sec61 at the } \\
\text { channel forming translocon complex for pro- } \\
\text { tein translocation across the ER }\end{array}$ & $\begin{array}{l}\text { ER (expressed at high levels in the } \\
\text { placenta, liver, muscle, pancreas; low in } \\
\text { the brain, lung, and kidney) }\end{array}$ \\
\hline $\begin{array}{l}\text { Calcium transporting ATPase } \\
\text { [P22700] }\end{array}$ & $\begin{array}{l}\text { Drosophila } \\
\text { melanogaster (fruit fly) }\end{array}$ & Reversible $\mathrm{Ca}^{2+}$ transport & Via ER and plasmalemma \\
\hline Trypsin [P00761] & Sus scrofa (wild boar) & Serine protease & $\begin{array}{l}\text { In digestive tract (synthesised in pancreas), } \\
\text { localised in plasmalemma (Takeuchi et al. } \\
\text { 2000) }\end{array}$ \\
\hline $\begin{array}{l}\mathrm{Na}^{+} / \mathrm{K}^{+} \text {-ATPase, a-subunit } \\
{[\mathrm{P05025]}}\end{array}$ & $\begin{array}{l}\text { Torpedo californica } \\
\text { (Pacific electric ray) }\end{array}$ & $3 \mathrm{Na}^{+} / 2 \mathrm{~K}^{+}$exchange & Plasmalemma \\
\hline Gelsolin-like protein 1 [Q7JQD3] & $\begin{array}{l}\text { Lumbricus terrestris } \\
\text { (common earth } \\
\text { worm) }\end{array}$ & $\begin{array}{l}\text { Regulator of actin filament assembly and } \\
\text { disassembly }\end{array}$ & $\begin{array}{l}\text { Plasma and intracellular membranes, } \\
\text { including ER, cortical vesicles and } \\
\text { mitochondria, plus short actin filaments } \\
\text { adhering to the plasma membrane (Hartwig } \\
\text { et al. 1989) renal brush border membranes }\end{array}$ \\
\hline $\begin{array}{l}\text { Malate dehydrogenase } \\
\text { cytoplasmic [Q6PAB3] }\end{array}$ & $\begin{array}{l}\text { Xenopus laevis } \\
\text { (African clawed frog) }\end{array}$ & $\begin{array}{l}\text { Oxidation of malate to oxaloacetate; confers } \\
\text { selectivity of the nucleic acid-conducting } \\
\text { channel in renal brush border membranes } \\
\text { (Hanss et al. 2002) }\end{array}$ & Renal brush border membranes \\
\hline $\begin{array}{l}\text { Guanine nucleotide- binding } \\
\text { protein subunit } \beta-1 \text { [P17343] }\end{array}$ & $\begin{array}{l}\text { Caenorhabditis } \\
\text { elegans }\end{array}$ & $\begin{array}{l}\text { Involved in Gaßy activation of phospholipase } \\
\text { c activity in a cellular signalling process } \\
\text { (Yan et al. 2007) }\end{array}$ & Localisation not disclosed \\
\hline $\begin{array}{l}\text { Ras-related protein O-Rab1 } \\
\text { [P22125] }\end{array}$ & $\begin{array}{l}\text { Discopyge ommata } \\
\text { (ocellated electric ray) }\end{array}$ & Probably involved in vesicular traffic & $\begin{array}{l}\text { O-Rab1 was found largely in the synaptic } \\
\text { vesicle fraction (Ngsee et al. 1991) }\end{array}$ \\
\hline Enolase [002654] & $\begin{array}{l}\text { Loligo pealei (longfin } \\
\text { inshore squid) }\end{array}$ & $\begin{array}{l}\text { Conversion of 2-phosphoglycerate } \leftrightarrow \\
\text { phosphenolpyruvate }+\mathrm{H}_{2} \mathrm{O}\end{array}$ & $\begin{array}{l}\text { Cytoplasm and plasma membrane of } \\
\text { synaptosomes (Ueta et al. 2004) }\end{array}$ \\
\hline $\begin{array}{l}\text { 2,3-bisphosphoglycerate- } \\
\text { dependent phosphoglycerate } \\
\text { mutase [B6IYD3] }\end{array}$ & $\begin{array}{l}\text { Rhodospirillum } \\
\text { centenum SW }\end{array}$ & $\begin{array}{l}\text { Catalyses the interconversion of } \\
\text { 2-phosphoglycerate and 3-phosphoglycerate }\end{array}$ & \\
\hline $\begin{array}{l}\text { Ras-related protein Rap-1b } \\
\text { [A5A6J7] }\end{array}$ & $\begin{array}{l}\text { Pan troglodytes } \\
\text { (chimpanzee) }\end{array}$ & $\begin{array}{l}\mathrm{Ca}^{2+} \text { ATPase effector } \\
\text { (Lacabaratz-Porret et al. 1998) }\end{array}$ & $\begin{array}{l}\text { Plasmalemma (Marridonneau-Parini and de } \\
\text { Gunzburg 1992; Mollinedo et al. 1993) }\end{array}$ \\
\hline
\end{tabular}

protein), protein sorting at trans-Golgi network and recruitment of clathrin to the membrane (AP-1 complex, clathrin heavy chain 1 ), protein trafficking via COPI or clathrin-coated vesicles from ER to Golgi and plasmalemma (ADP-ribosilation factor $1=$ Arf 1), tubulovesicular recycling of protein from Golgi $\rightarrow$ ER (glyceraldehyde-3phosphate dehydrogenase 2 ) and synaptic vesicle traffic $(\mathrm{O}$ Rab1). Further, a few constructional processes are involved like fragmentation and reassembly of Golgi stacks during and after mitosis + formation of tER (transitional endoplasmic reticulum ATPase), contractile ring formation (actin, cytoplasmic 2) and regulation of actin filament assembly + disassembly (gelsolin-like protein 1). Subsequently, we record a number of cellular signalling components like neural signalling GTPase (guanine nucleotide-binding protein G (o) or $\mathrm{G}(\mathrm{q})$, subunit $\alpha$ ), integrin signalling at adhesions

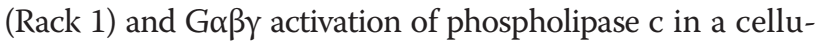
lar signalling process (guanine nucleotide-binding protein subunit $\beta-1$ ). Another constructional component is heat-shock $70 \mathrm{kDa}$ protein, yielding conservation of protein shape and protection against stress. In addition, we noticed a number of metabolic enzymes ( $\alpha$-amylase, glycogen phosphorylase, trypsin, enolase) and cationactivated enzymes (sarcoplasmic/endoplasmic reticulum calcium ATPase as modulated by Rap-1b, calciumtransporting ATPase, $\mathrm{Na}^{+} / \mathrm{K}^{+}$-ATPase) and the selectivity conferring protein in renal brush border nucleic acid conducting channel (cytoplasmic malate dehydrogenase).

The contribution of cellular signalling components appears to be modest in number but has been encountered 
Table 3 Proteins of cytoskeleton and muscle

\begin{tabular}{|c|c|c|c|}
\hline Protein & Eucaryote & Function & Localisation \\
\hline Cytoplasmic actin [Q93129] & $\begin{array}{l}\text { Branchiostoma Belcheri } \\
\text { (Belcher's lancelet) }\end{array}$ & $\begin{array}{l}\text { Transport track for myosin + support of cell } \\
\text { stability (Pollard and Cooper 2009) }\end{array}$ & Cytoskeleton \\
\hline $\begin{array}{l}\text { Actin, cytoplasmic } 1 \\
\text { ( } \beta \text {-actin) }[\text { P79818] }\end{array}$ & $\begin{array}{l}\text { Oryzias latipes (Japanese } \\
\text { medaka) }\end{array}$ & Idem & Idem \\
\hline Actin [016808] & $\begin{array}{l}\text { Maietiola destructor (Hessian } \\
\text { fly or barley midge) }\end{array}$ & $\begin{array}{l}\text { Cell support + providing trafficking routes } \\
\text { for myosin in signal transduction (Pollard } \\
\text { and Cooper) }\end{array}$ & cytoskeleton, microfilaments \\
\hline $\begin{array}{l}\text { Actin, cytoskeletal 1A } \\
\text { [P53472] }\end{array}$ & $\begin{array}{l}\text { Strongylocentrotus purpuratus } \\
\text { (purple sea urchin) }\end{array}$ & Idem & Idem \\
\hline $\begin{array}{l}\text { Actin, non-muscle } 6.2 \\
\text { [P17126] }\end{array}$ & $\begin{array}{l}\text { Hydra vulgaris (fresh water } \\
\text { polyp) }\end{array}$ & Idem & Idem \\
\hline Actin-3 [P53457] & $\begin{array}{l}\text { Diphyllobothrium dentricum } \\
\text { (flatworm) }\end{array}$ & $\begin{array}{l}\text { Idem in metazoan muscle cells actin forms } \\
\text { a scaffold in which myosin generates force } \\
\text { to support muscle contraction }\end{array}$ & Idem \\
\hline Actin-3 [P41113] & Podocoryne carnea (jellyfish) & As for cytoplasmic actin & Idem \\
\hline Actin-18 [P07828] & $\begin{array}{l}\text { Dictyostelium discoideum } \\
\text { (amoeba) }\end{array}$ & Idem & Idem \\
\hline Actin [017320] & Crassostrea gigas (Pacific oyster) & Idem & Idem \\
\hline Actin [P50138] & Puccinia graminis(mould) & Idem & Idem \\
\hline Actin, clone 205 [P18600] & Artemia sp. (crustacean) & Idem & Idem \\
\hline Plastin-1 [P19179] & Gallus gallus (chicken) & Actin bundling protein & Cytoskeleton \\
\hline $\begin{array}{l}\text { Spectrin a-chain, non- } \\
\text { erythrocytic } 1 \text { [P07751] }\end{array}$ & Gallus gallus & $\begin{array}{l}\text { Playing an important role in membrane } \\
\text { organisation }\end{array}$ & $\begin{array}{l}\text { Cytoplasm, cytoskeleton and } \\
\text { cell cortex }\end{array}$ \\
\hline Spectrin $\beta$-chain [Q00963] & $\begin{array}{l}\text { Drosophila melanogaster } \\
\text { (fruit fly) }\end{array}$ & $\begin{array}{l}\text { Spectrin links the actin cytoskeleton to the } \\
\text { plasma membrane, thus forming a flexible } \\
\text { scaffold in the cell cortex (Djinovic-Carugo } \\
\text { et al. 2002) }\end{array}$ & Plasmalemma + cytoskeleton \\
\hline $\begin{array}{l}\text { Heat shock cognate protein } \\
\text { HSP90- } \beta \text { [Q04619] }\end{array}$ & Gallus gallus (chicken) & $\begin{array}{l}\text { Early embryonic development, germ cell } \\
\text { maturation, cytoskeletal stabilisation, } \\
\text { cellular transformation, signal transduction, } \\
\text { long-term cell adaptation (Sreedhar et al. } \\
\text { 2004) }\end{array}$ & $\begin{array}{l}\text { Cytoplasm + cytoskeleton } \\
\text { (microtubules and actin filaments, } \\
\text { Cambiazo et al. 1999) }\end{array}$ \\
\hline Radixin [P26043] & Mus musculus (mouse) & $\begin{array}{l}\text { Participates in signal transduction and } \\
\text { regulates cell migration and intercellular } \\
\text { adhesion via Rac } 1 \text { (Valderrama et al. 2012) }\end{array}$ & $\begin{array}{l}\text { Linking plasmalemma to actin } \\
\text { filaments }\end{array}$ \\
\hline Ubiquitin [Q86WD4] & $\begin{array}{l}\text { Encephalitozoon cuniculi } \\
\text { (protozoan) }\end{array}$ & $\begin{array}{l}\text { Involved in the ubiquitin proteasome } \\
\text { pathway (Hegde 2010) }\end{array}$ & $\begin{array}{l}\text { Plasmalemma and cytoskeleton } \\
\text { (microtubules) (Murti et al. 1988, } \\
\text { Hicke and Dunn 2003) }\end{array}$ \\
\hline $\begin{array}{l}\text { T-complex protein } 1 \text { subunit } \\
\text { a [P50157] }\end{array}$ & $\begin{array}{l}\text { Ambystoma mexicanum } \\
\text { (axolotl, salamander) }\end{array}$ & $\begin{array}{l}\text { TCP-1 is chaperonin, involved in protein } \\
\text { folding, e.g. of actin and tubulin } \\
\text { (Souès et al. 2003; Yam et al. 2008) }\end{array}$ & $\begin{array}{l}\text { Nucleus, cytoskeleton (microtubule } \\
\text { organising centre) and cytoplasm } \\
\text { (Souès et al. 2003) }\end{array}$ \\
\hline Tubulin $\beta$-chain [P11833] & $\begin{array}{l}\text { Paracentrotus lividus } \\
\text { (sea urchin) }\end{array}$ & $\begin{array}{l}\text { Mitosis, intracellular vesicle transport } \\
\text { (www.buzzle.com/articles/microtubules- } \\
\text { function. html) }\end{array}$ & Part of cytoskeleton: microtubules \\
\hline Tubulin $\beta-2$ chain [P52275] & Caenorhabditis elegans & $\begin{array}{l}\text { Part of transport track for ATP-driven } \\
\text { vesicle movement or chromosomes in } \\
\text { mitosis and meiosis }\end{array}$ & Cytoskeleton: microtubules \\
\hline Tubulin a-1A chain [A5A6J1] & $\begin{array}{l}\text { Pan troglodytes } \\
\text { (chimpanzee) }\end{array}$ & $\begin{array}{l}\text { Involved in supporting the cell shape } \\
\text { and transport of vesicles }\end{array}$ & Idem \\
\hline Tubulin a-3 chain [P05214] & Mus musculus (house mouse) & cf. Tubulin $\beta$-chains & Idem \\
\hline Myosin-9 [P35579] & Homo sapiens (human) & $\begin{array}{l}\text { Cytokinesis: vesicle transport via actin } \\
\text { filaments, cell shape, secretion and capping }\end{array}$ & $\begin{array}{l}\text { Cytoskeleton, cell cortex together } \\
\text { with actin filaments at lamellipodia } \\
\text { and at the leading edge of migrating cells }\end{array}$ \\
\hline
\end{tabular}


Table 3 Proteins of cytoskeleton and muscle (Continued)

\begin{tabular}{|c|c|c|c|}
\hline Elongation factor 1a [P02993] & Artemia salina (brine shrimp) & $\begin{array}{l}\text { Promoting the GTP-dependent binding of } \\
\text { aminoacyl-tRNA to the A-site of ribosomes } \\
\text { during protein biosynthesis }\end{array}$ & $\begin{array}{l}\text { Cytoskeleton (actin filaments) } \\
\text { (Liu et al. 1996) }\end{array}$ \\
\hline $\begin{array}{l}\text { Eucaryotic initiation factor } \\
4 \mathrm{~A}-\mathrm{I} \text { [A5A6N4] }\end{array}$ & $\begin{array}{l}\text { Pan troglodytes } \\
\text { (chimpanzee) }\end{array}$ & $\begin{array}{l}\text { ATP-dependent RNA helicase, involved in } \\
\text { mRNA binding to the ribosome }\end{array}$ & Cytoskeleton (Ziegler et al. 2012) \\
\hline Myosin-11 [P10587] & Gallus gallus (chicken) & Involved in contraction & Smooth muscle \\
\hline $\begin{array}{l}\text { Myosin catalytic light chain } \\
\text { LC-1 [P05945] }\end{array}$ & $\begin{array}{l}\text { Todarus pacificus (Japanese } \\
\text { flying squid = cephalopod) }\end{array}$ & $\begin{array}{l}\text { Is dependent on } \mathrm{Ca}^{2+} \text { binding for muscle } \\
\text { contraction; in molluscan muscle } \mathrm{Ca}^{2+} \\
\text { regulation is associated with myosin rather } \\
\text { than with actin }\end{array}$ & Mantle muscle \\
\hline $\begin{array}{l}\text { Myosin essential adductor } \\
\text { muscle light chain [P07290] }\end{array}$ & $\begin{array}{l}\text { Mizuhopecten yessoensis } \\
\text { (Yesso scallop, bivalve) }\end{array}$ & Idem & Idem \\
\hline Paramyosin [O96064] & $\begin{array}{l}\text { Mytilus galloprovincialis } \\
\text { (Mediterranean mussel) }\end{array}$ & Attachment to the substrate & $\begin{array}{l}\text { Mytilus anterior byssus retractor } \\
\text { paramyosin (thick filaments at the } \\
\text { myofibrils) }\end{array}$ \\
\hline $\begin{array}{l}\text { Adductor muscle actin } \\
\text { (precursor) [Q26065] }\end{array}$ & $\begin{array}{l}\text { Placopecten magellanicus } \\
\text { (sea scallop) }\end{array}$ & Involved in muscle contraction & Location is in the name \\
\hline $\begin{array}{l}\text { Actin, muscle (precursor) } \\
{[\text { P12431] }}\end{array}$ & $\begin{array}{l}\text { Strongylocentrotus purpuratus } \\
\text { (purple sea urchin) }\end{array}$ & Is involved in muscle contraction & Idem \\
\hline Tropomyosin [Q9GZ71] & $\begin{array}{l}\text { Haliotis diversicolor (variously } \\
\text { coloured abalone) }\end{array}$ & $\begin{array}{l}\text { In association with the troponin complex } \\
\text { plays a central role in the } \mathrm{Ca}^{2+} \text {-dependent } \\
\text { regulation of muscle contraction }\end{array}$ & Idem \\
\hline $\begin{array}{l}\text { a-Actinin, sarcomeric } \\
\text { [P18091] }\end{array}$ & $\begin{array}{l}\text { Drosophila melanogaster } \\
\text { (fruit fly) }\end{array}$ & $\begin{array}{l}\text { F-actin cross-linking protein, anchoring } \\
\text { actin to a variety of intracellular structures. } \\
\text { By allowing insertion of thick filaments } \\
\text { (myosin) the thin filaments (actin) are led } \\
\text { to contraction (Stryer 1995a) }\end{array}$ & \\
\hline Actin, larval muscle [P02574] & $\begin{array}{l}\text { Drosophila melanogaster } \\
\text { (fruit fly) }\end{array}$ & $\begin{array}{l}\text { Actin, together with myosin, is involved in } \\
\text { muscle contraction }\end{array}$ & \\
\hline $\begin{array}{l}\text { Myosin heavy chain, striated } \\
\text { muscle [P24733] }\end{array}$ & $\begin{array}{l}\text { Argopecten irradians } \\
\text { (baby scallop) }\end{array}$ & $\begin{array}{l}\text { Involved in muscle contraction (Nyitray } \\
\text { et al. 1991) }\end{array}$ & \\
\hline
\end{tabular}

before in a proteomic analysis of Mytilus galloprovincialis and Mytilus trossulus: three to four signalling components in a total of 47 to 61 proteins, i.e. $6.4 \%$ to $6.5 \%$ (Tomanek and Zuzow 2010).

The cytoskeletal and muscle components (Table 3) with their numbers between parentheses can be summarised as follows: actin non-muscle (11), cytoskeleton (microfilaments) $=$ transport track for myosin; linkers of actin to plasma membrane: plastin, radixin, spectrin $\alpha$ and $\beta$ chains (4); myosin-9, involved in vesicle transport via actin filaments (1); tubulin $\alpha$ and $\beta$ chains (microtubules, involved in ATP-driven vesicle transport or transport of chromosomes in mitosis and meiosis) (4), myosin muscle, involved in contraction: myosin-11 (smooth muscle) (1), myosin LC-1 + heavy chain + adductor muscle light chain (3), paramyosin (byssus retractor muscle) (1), adductor muscle actin (precursor) $\rightarrow$ contraction (1), actin, muscle precursor, tropomyosin, $\alpha$-actinin, actin larval muscle (4).

Additional cytoskeletal organised components are: the chaperonin TCP-1, heat-shock cognate protein HSP90- $\beta$ (with a plurality of functions), ubiquitin (involved in proteolysis), elongation factor $1 \alpha$ (involved in protein synthesis) and eucaryotic initiation factor 4A-I (involved in mRNA binding to the ribosome).

After corrections for bacterial and plant contaminations in Tables 1 and 2, we come to a total of M. leucophaeata-related analyses of 112 . The analyses, related to the cytoskeletal and muscle components (1st paragraph of Table 3) amount to 30, i.e. $26.8 \%$ of all analyses. Similar results have been scored by Tomanek and Zuzow (2010) for M. trossulus and M. galloprovincialis: $16.4 \%$ and $25.5 \%$, respectively. In a later study (Fields et al. 2012), they even scored $39.4 \%$ and $52.8 \%$, respectively. These numbers underline the importance for these waterbound animals of a sturdy built body with solid protection against predators. Intracellular stability by the cytoskeleton via linking of actin filaments to the cell membrane, presence of adductor muscles for closure of the shell halves provide additional support for the above ideas, and of course, the presence of paramyosin is essential for binding of the animal to the substrate, including stones and ship walls that bring them to the harbours.

In this last part of our analyses (Table 4), we find only transport vesicles (V-type $\mathrm{H}^{+}$-ATPase, major vault protein); histones $\mathrm{H} 2 \mathrm{~A}, \mathrm{H} 2 \mathrm{AV}, \mathrm{H} 2 \mathrm{~B}, \mathrm{H} 3$ and $\mathrm{H} 4$; proteasome 
Table 4 Proteins from cellular vacuoles, ribonucleoprotein particles (vaults), nuclei and mitochondria

\begin{tabular}{|c|c|c|c|}
\hline Protein & Eucaryote & Function & Localisation \\
\hline $\begin{array}{l}\text { V-type proton ATPase catalytic } \\
\text { subunit A [P314400] }\end{array}$ & $\begin{array}{l}\text { Manduca sexta } \\
\text { (tobacco horn worm) }\end{array}$ & $\begin{array}{l}\text { Involved in cellular trafficking, exocytosis and } \\
\text { endocytosis, and interaction with the cytoskeleton } \\
\text { (Marshansky and Futai 2008) }\end{array}$ & Cellular vacuoles \\
\hline Major vault protein [Q5EAJ7] & $\begin{array}{l}\text { Strongylocentrotus purpuratus } \\
\text { (purple sea urchin) }\end{array}$ & $\begin{array}{l}\text { Signal pathway regulation and immune defence } \\
\text { (Berger et al. 2009) }\end{array}$ & $\begin{array}{l}\text { Ribonucleoprotein particles } \\
(41 \times 41 \times 71.5 \mathrm{~nm}) \text { or vaults }\end{array}$ \\
\hline Histone H2A.V [P02272] & Gallus gallus (chicken) & $\begin{array}{l}\text { Histones play a central role in transcription regulation, } \\
\text { DNA repair, DNA replication and chromosomal stability }\end{array}$ & Part of nucleosome core (nuclei) \\
\hline Histone H2A [P02268] & $\begin{array}{l}\text { Sepia officinalis } \\
\text { (common cuttlefish) }\end{array}$ & See above and below & See above and below \\
\hline $\begin{array}{l}\text { Histone H2B, gonadal } \\
\text { [P02284] }\end{array}$ & $\begin{array}{l}\text { Patella granatina } \\
\text { (sand paper limpet) }\end{array}$ & $\begin{array}{l}\text { See above; further, histones and histone fragments } \\
\text { circulate via transporters through the cytoplasm and } \\
\text { so may be transferred to the plasma membrane } \\
\text { (Schuurmans Stekhoven et al. 2004) from where they } \\
\text { execute their anti-microbial activity (Seo et al. 2011) }\end{array}$ & $\begin{array}{l}\text { Nuclei, cytoplasm, and } \\
\text { plasmalemma }\end{array}$ \\
\hline Histone H3 [P02299] & $\begin{array}{l}\text { Drosophila melanogaster } \\
\text { (fruit fly) }\end{array}$ & See above & See over \\
\hline Histone H4 [P35059] & $\begin{array}{l}\text { Acropora formosa } \\
\text { (stony corals) }\end{array}$ & See above & See over \\
\hline $\begin{array}{l}\text { Proteasome subunit a } \\
\text { type-2 [Q73672] }\end{array}$ & $\begin{array}{l}\text { Carassius auratus } \\
\text { (gold fish) }\end{array}$ & Cleavage of peptide bonds with very broad specificity & Cytoplasm and nucleus \\
\hline $\begin{array}{l}\text { Proteasome subunit a } \\
\text { type-5-A [O81149] }\end{array}$ & $\begin{array}{l}\text { Arabidopsis thaliana } \\
\text { (thale cress) }\end{array}$ & Brake down of damaged or redundant proteins & Cytosol and nucleus \\
\hline $\begin{array}{l}\text { Proteasome subunit a } \\
\text { type-7 [013268] }\end{array}$ & Gallus gallus (chicken) & $\begin{array}{l}\text { ATP dependent cleavage of peptide bonds with } \\
\text { broad specificity }\end{array}$ & Cytoplasm and nucleus \\
\hline 14-3-3 protein ع [P92177] & $\begin{array}{l}\text { Drosophila melanogaster } \\
\text { (fruit fly) }\end{array}$ & $\begin{array}{l}\text { Multifunctional: regulation of enzymatic activity, } \\
\text { regulation of subcellular localisation, inhibition of } \\
\text { protein-protein or protein-DNA interaction, protection } \\
\text { against dephosphorylation or proteolytic degradation, } \\
\text { stabilisation of multiprotein complexes } \\
\text { (Obsil and Obsilova 2011) }\end{array}$ & $\begin{array}{l}\text { Plasmalemma, mitochondrion, } \\
\text { nucleus }\end{array}$ \\
\hline $\begin{array}{l}\text { ATP synthase, subunit a } \\
\text { [Q9XXK1] }\end{array}$ & $\begin{array}{l}\text { Caenorhabditis elegans } \\
\text { (round worm) }\end{array}$ & ATP synthesis & Mitochondrion \\
\hline $\begin{array}{l}\text { ATP synthase, subunit } \\
\beta \text { precursor [Q5ZLC5] }\end{array}$ & Gallus gallus (chicken) & ATP synthesis & Mitochondrion \\
\hline $\begin{array}{l}\text { Succinate dehydrogenase } \\
\text { [Q28ED0] }\end{array}$ & $\begin{array}{l}\text { Xenopus tropicalis } \\
\text { (Western clawed frog) }\end{array}$ & Transfer of electrons to coenzyme Q & Mitochondrion \\
\hline $\begin{array}{l}\text { ADP/ATP carrier protein } 3 \\
\text { [O49447] }\end{array}$ & $\begin{array}{l}\text { Arabidopsis thaliana } \\
\text { (thale cress) }\end{array}$ & $\begin{array}{l}\text { Exchange of ADP and ATP across the mitochondrial } \\
\text { inner membrane }\end{array}$ & Idem \\
\hline $\begin{array}{l}\text { Probable malate } \\
\text { dehydrogenase } 3 \text { [Q54VM2] }\end{array}$ & $\begin{array}{l}\text { Dictyostelium discoideum } \\
\text { (amoeba) }\end{array}$ & Oxidation of malate to oxaloacetate & $\begin{array}{l}\text { Cytoplasm and mitochondria } \\
\text { (Danis and Farkas 2009; Gietl 1992) }\end{array}$ \\
\hline $\begin{array}{l}\text { Phosphoenolpyruvate } \\
\text { carboxykinase [Q05893] }\end{array}$ & $\begin{array}{l}\text { Ascaris suum } \\
\text { (pig roundworm) }\end{array}$ & $\begin{array}{l}\text { Conversion of oxaloacetate to phosphoenolpyruvate } \\
\text { and vice versa }\end{array}$ & Mitochondria (Stryer 1995b) \\
\hline
\end{tabular}

subunit $\alpha$ type-2, $-5 \mathrm{~A}$ and -7 ; the $14-3-3$ protein $\varepsilon$; ATP synthase subunit $\alpha-+\beta$-precursor; the citric acid cycle enzymes succinate dehydrogenase; probable malate dehydrogenase 3; and phosphoenolopyruvate carboxykinase that is responsible for the conversion of oxaloacetate to phosphoenolpyruvate in the gluconeogenesis pathway (Stryer 1995b); and the mitochondrial ADP/ATP exchanger.

This gives a fair picture of what is going on in the subcellular compartments indicated, but some of the animals (or plants) of comparison (second column) require some criticism with regard to their comparability as will be brought forward in the discussion of Tables 3 and 4 .
As mentioned in the 'Introduction' section, we were also interested in the protein chemical developments that had taken place in the mussel's long history. For that reason, we have registered the generation time for all vertebrates and invertebrates that had provided sequences that led to the identification of proteins that have been presented in Tables 1, 2, 3 and 4. Proteins that could be considered as intestinal contaminants: bacterial proteins, but also a single plant, living in flooded wetlands, have been omitted. Figure 2A,B provides the graphical result of MYA from 1,100 to zero vs. the sum of the vertebrate + invertebrate contribution. It can be seen that the 


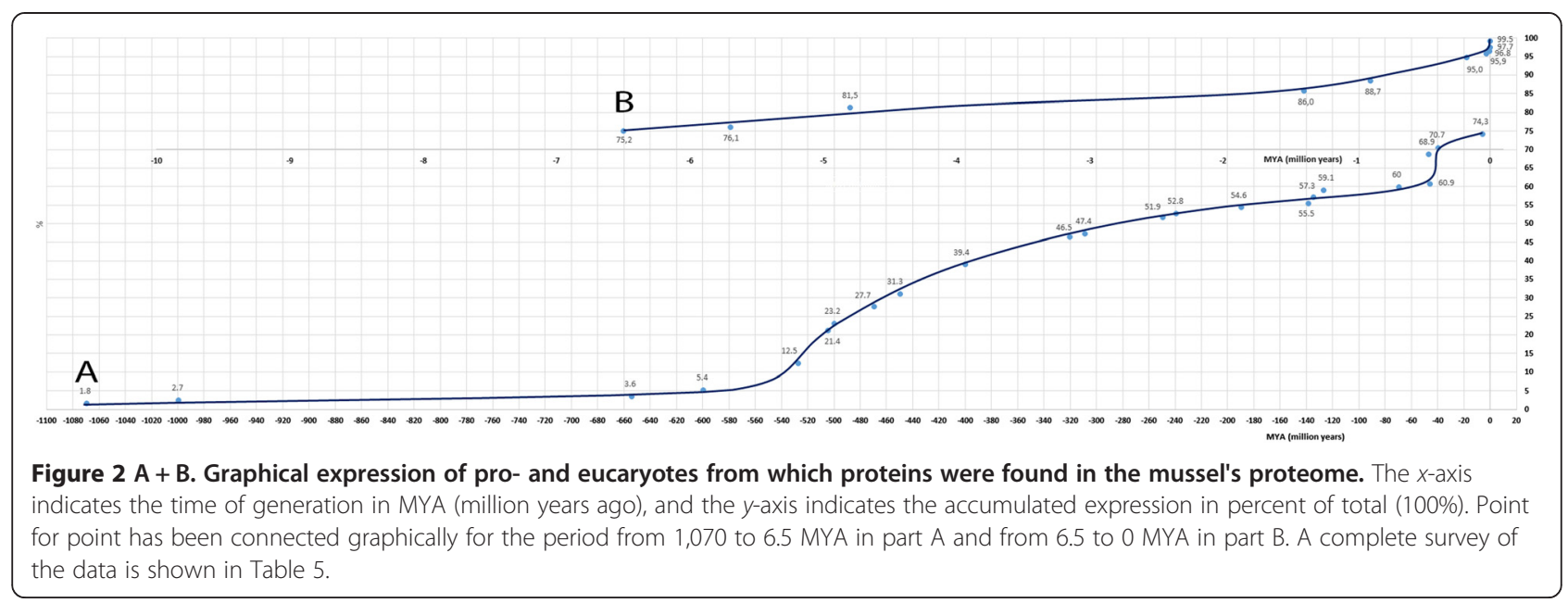

graph curves upward from 600 to 500 MYA, thereby covering the generation of bivalves. From 320 to 50 MYA, the line is linear, covering the insect Drosophila melanogaster (321 MYA) teleosts Takifugu rubripes and goldfish (70 to 48 MYA). Thereupon follows a second uprise until 4.75 MYA in which period Birds (Phasianidae), Decapoda (brine shrimp), Muridae (rat and house mouse), rabbit and the Japanese medaka participate. After this period, there is some levelling off, but is followed by a third uprise, lasting from 1.4 to 0 MYA (Figure 2B). Animals and fungi, involved in this period, are: cow (5), chimpanzee (3), Homo sapiens (7), $\operatorname{dog}(1)$, goat (1), stemrust (1) and wild boar (2) (Table 5). From the total of 20 items, 10 (50\%) belong to Table 1 and are part of ribosomes that are involved in the protein synthesis machinery. The only cow that was missing in Table 1 can be found in Table 2 as a provider of cyclophilin $\mathrm{C}$, a protein folding catalyst on the ER. Chimpanzee can be found in Table 2 at Ras-related protein Rap$1 \mathrm{~b}$ and in Table 3 at tubulin $\alpha-1$ A chain and eucaryotic initiation factor 4A-I. Rap-1b is a cellular signalling component in neuronal cells (Sahyoun et al. 1991) and lymphocytes (Awasthi et al. 2010). Tubulin $\alpha-1$ A chain is part of the cytoskeleton (microtubules), which supports the cell shape and serves as transport track for vesicles. Eucaryotic initiation factor 4A-I is involved in binding of the messenger RNA to the ribosome. H. sapiens (human) is for about half categorised under the ribosomes at Table 1. Further, humans can be found in Table 2 at $\alpha$-amylase, glycogen phosphorylase, and dolichyl-diphosphooligosaccharide protein glycosyltransferase and in Table 3 at myosin-9. Functions are: provision of glucose from its polymers, protein transport across the ER and transport of vesicles along actin filaments. The only dog is related to protein synthesis (Table 1); stemrust (Puccinia graminis) is also related to the cytoskeletal actin (Table 3) and wild boar to transitional ER ATPase (TERA) and the serine protease trypsin
(Table 2). The first is involved in breakdown and repair of Golgi stacks during and after mitosis, respectively, plus formation of the transitional ER. The second is involved in proteolysis.

Summarising all processes involved in the third proteochemical uprise (covering the Pleistocene and Holocene) shows a composition of protein synthesis, breakdown, folding and transportation across the ER. In addition, binding of messenger RNA to the ribosome, cellular signalling, microtubular vesicle transport, breakdown and repair of Golgi stacks during and after mitosis and formation of the transitional ER are also involved. Glucose supply is provided by $\alpha$-amylase and glycogen phosphorylase; in the latter case yielding glucose-1P. All these processes are essential for survival of the animal, and during its evolution, it may have been necessary to adapt to the changing environmental conditions.

In addition, we liked to analyse also the second proteochemical uprise (48 to 4.75 MYA, corresponding with half Eocene to second half of Pliocene). Animals belonging to this time range are chicken (9), brine shrimp (2), house mouse (4), rabbit (1), Japanese medaka (1), and Rattus norvegicus (6), with the number of recorded protein components between parentheses. Summation yields a number of 23, slightly more than the third uprise with 20 components, but taking an appreciably longer time span: 43 vs. 1.4 million years.

Processes involved in this second period of development of the mussel are: transcription regulation, DNA repair and replication + chromosome stabilisation (chicken histone H2A. V: 1 item), protein synthesis at the ER by ribosomes from Muridae (Rattus and Mus musculus: 5 items), binding of aminoacyl-tRNA to the ribosomes in protein synthesis (elongation factor $1 \alpha$, brine shrimp: 1 item), protein folding at the ER (endoplasmin, rabbit: 1 item), cargo sorting at the plasma membrane and trans-Golgi network 
Table 5 Geologic time table of animal, plants, amoebae and fungi's contribution to the proteomics of $M$. leucophaeata

Component with proteins Time of generation (MYA) Co

Amoeba (Dictyosteliidae): actin 18; probable malate dehydrogenase.

Encephalitozoon cuniculi (protozoon parasite): ubiquitin.

Starlet sea anemone (polyp): ribosomal subunit 40S-S3a.

Fission yeast (S. pombe): ribosomal subunit 60S-L7C; ADP-ribosylation factor 1 (Arf1).

Lancelet \& worms: ribosomal subunit 40S-SA; cytoplasmic actin; actin 3; gelsolin-like protein 1; guanine nucleotide-binding protein; tubulin $\beta$-2 chain; ATP synthase, subunit $a_{;}$phosphoenolpyruvate carboxykinase.

Bivalves: ribosomal subunit 40S-SA; ribosomal subunit 40S-S18; ribosomal subunit 40S-S19; guanine nucleotide-binding protein, subunit $\beta$; guanine nucleotide-binding protein $\mathrm{G}(\mathrm{o})$, subunit $\mathrm{a}$; actin; myosin essential adductor muscle light chain; paramyosin; adductor muscle actin (precursor); myosin heavy chain.

Hydrozoa (Hydra vulgaris; Podocoryne carnea): actin, non-muscle; actin 3.

Gastropoda: Lymnaea stagnalis: guanine nucleotide-binding protein $\mathrm{G}(\mathrm{q})$, subunit a; 2005) Biomphalaria glabrata; guanine nucleotide-binding protein subunit $\beta$-2-like, Rack 1; Aplysia californica: 78 kDa glucose-regulated protein; Haliotis diversicolor: tropomyosin; Patella granatina: histone H2B, gonadal.

Cephalopoda: ribosomal subunit 40S-S26; enolase; myosin catalytic light chain LC-1; histone H2A.

Echinodermata (Strongylocentrotus purpuratus): actin, cytoskeletal 1A; actin, muscle (precursor); major vault protein.

Insects (Arthropoda, Hexopoda): ribosomal subunit 40S-S4; ribosomal subunit 60S-L5; ribosomal subunit 60S-L8; ribosomal subunit 60S-L17; actin; V-type proton ATPase catalytic subunit A.

Fruit fly (Drosophila melanogaster): ribosomal subunit 40S-S14; heat-shock $70 \mathrm{kDa}$ protein cognate 3 ; $\mathrm{Ca}^{2+}$ transporting ATPase; spectrin $\beta$-chain; a-actinin, sarcomeric; actin, larval muscle; histone H3; 14-3-3 protein $\varepsilon$.

Fungi (Saccharomyces cerevisiae): ribosomal subunit 60S-L16a.

Amphibians (Xenopus tropicalis, Xenopus laevis): ribosomal subunit 40S-S13; ribosomal subunit 60S-L4b; actin, cytoplasmic 2; malate dehydrogenase, cytoplasmic; succinate dehydrogenase.

(Anthozoa, stony corals): histone $\mathrm{H} 4$

Elasmobranchii (rays): $\mathrm{Na}^{+} / \mathrm{K}^{+}$-ATPase; Ras-related protein O-Rab1.

Amphibians (salamander): T-complex protein 1, subunit a.

Teleosts (channel catfish): ribosomal subunit 40S-S6; ribosomal subunit 60S-L7a.

Plantae (cruciferae, thale cress): proteasome subunit a type-5-A; ADP/ATP carrier protein 3.

Teleosts (Takifugu rubripes): ribosomal subunit 40S-S24.

Goldfish: proteasome subunit a type-2.

Birds (chicken, Galliformes, Phasianidae): sarcoplasmic/endoplasmic reticulum ATPase 3; heat-shock 70 kDa protein; plastin-1; spectrin a chain, non-erythrocytic 1; heat-shock cognate protein HSP90- $\beta$; myosin-11; histone H2A.V; proteasome subunit a type-7; ATP synthase, subunit $\beta$ precursor.

Decapoda (brine shrimp): actin, clone 205; elongation factor 1 a.

Mammals (house mouse): ribosomal subunit 40S-S16; AP-1 complex, subunit $\beta-1$; radixin; tubulin a-3 chain.

Rabbit: endoplasmin.

Teleosts (Japanese medaka); actin, cytoplasmic 1 (ß-actin).
1070 (Wegener Parfrey et al. 2011)

1000 (Hedges 2002)

655 (Wegener Parfrey et al. 2011)

600 (Wegener Parfrey et al. 2011)

551 to 505 (Bagley 2013)

Contribution Sum

(\%)

1.8

(\%)

appros 2008)

approximately 505 (Cartwright et al. 2007)

500 to 440 ([PPT] Life and Geologic Time)

approximately 450 (Smith 1984)

400 (Grimaldi and Engel 2005)

321 (Wegener Parfrey et al. 2011)

190 (prehistoric sharks - megalodon, fossil teeth, shark attacks) (Pre-Historic Sharks)

139 (Zhang et al. 2005a)

160 to 110 (Volff 2005)

127 (Wegener Parfrey et al. 2011)

80 to 60 (Volff 2005)

49 to 46 (Wang et al. 2007)

58 to 37 (Mlikovský 1989)

40 (Baxeranis et al. 2006) 
Table 5 Geologic time table of animal, plants, amoebae and fungi's contribution to the proteomics of $M$. leucophaeata (Continued)

\begin{tabular}{|c|c|c|c|}
\hline $\begin{array}{l}\text { Rattus norvegicus: ribosomal subunit 40S-S27-like; ribosomal subunit 60S-L4; } \\
\text { ribosomal subunit 60S-L5; ribosomal subunit 60S-L26; clathrin heavy chain 1; } \\
\text { glyceraldehyde-3-phosphate dehydrogenase } 2 \text {. }\end{array}$ & $\begin{array}{l}6 \text { to } 3.5 \text { (Furano and Usdin 1995; } \\
\text { Verneau et al. 1998) }\end{array}$ & 5.4 & 81.5 \\
\hline $\begin{array}{l}\text { Cow: ribosomal subunit } 40 S-S 2 \text {; ribosomal subunit } 40 \text { S-S7; ribosomal } \\
\text { subunit } 40 \text { S-S9; ribosomal subunit 40S-S17; peptidyl-prolyl cis-trans isomerase } \\
\text { C (cyclophilin C). }\end{array}$ & 1.4 (Mac Hugh et al. 1997) & 4.5 & 86.0 \\
\hline $\begin{array}{l}\text { Chimpanzee: Ras-related protein Rap-1b; tubulin-1A chain; eucaryotic } \\
\text { initiation factor 4A-I. }\end{array}$ & 0.9 to 0.86 (Won and Hey 2005) & 2.7 & 88.7 \\
\hline $\begin{array}{l}\text { Homo sapiens: ribosomal subunit 40S-S3; ribosomal subunit 40S-S5; } \\
\text { ribosomal subunit 60S-L23a; a-amylase; glycogen phosphorylase; } \\
\text { dolichyl-diphosphooligosaccharide-protein glycosyltransferase subunit } \\
\text { STT3A; myosin-9. }\end{array}$ & 0.2 to 015 (Reid and Hetherington 2010) & 6.3 & 95.0 \\
\hline Dog (Canis lupus familiaris): ribosomal subunit 60S-L12. & 0.032 (Germonpré et al. 2009) & 0.9 & 95.9 \\
\hline Goat (Capra hircus): ribosomal subunit 40S-S18. & $\begin{array}{l}0.006 \text { to } 0.007 \text { (www.ansi.okstate.edu/breeds/ } \\
\text { goats/) }\end{array}$ & 0.9 & 96.8 \\
\hline Fungi (Puccinia graminis: stemrust): actin. & 0.0033 (Kislev 1982) & 0.9 & 97.7 \\
\hline Wild boar: transitional endoplasmic reticulum ATPase (TERA); trypsin. & 0.005 to 0 (Hardjasasmita 1987$)$ & 1.8 & 99.5 \\
\hline
\end{tabular}

Time is expressed in MYA (million years ago), and contribution in percent of total (112 items), excluding bacterial contamination and vegetable contribution from wetlands.

(clathrin heavy chain $1, R$. norvegicus: 1 item, and AP-1 complex, subunit $\beta-1, M$. musculus: 1 item), also including endocytosis.

Besides protein synthesis, folding and sorting, there is also the recycling from Golgi to ER (glyceraldehyde-3 phosphate dehydrogenase $2, R$. norvegicus: 1 item). Not only protein synthesis is involved, but also protein cleavage (proteasome subunit $\alpha$ type-7, chicken: 1 item). Protein is transcellularly transported via phosphorylation/ dephosphorylation of myosin on the cytoskeletal actin tracks. Components of this system are provided by brine shrimp (actin, clone 205: 1 item) and Japanese medaka (cytoplasmic actin: 1 item). Intracellular stability is given by linking of actin filaments to each other (plastin-1, chicken: 1 item) or to the plasma membrane (spectrin $\alpha$ chain, chicken: 1 item, and radixin, house mouse: 1 item). Intracellular vesicle transport is provided by tubulin $\alpha-3$ chain, which is also involved in mitosis (house mouse: 1 item). Heat-shock proteins: $70 \mathrm{kDa}$ and cognate protein HSP $90-\beta$ are involved in conservation of protein shape (anti-stress protectant) and cytoskeletal stabilisation + signal transduction (chicken: 2 items). Last, but not least, muscle contraction for closing and opening the valves is effected by sarcoplasmic/endoplasmic reticulum calcium ATPase 3 and myosin-11 (chicken: 2 items). Not to forget is ATP synthase (chicken: 1 item), which will make transportation and muscle contraction, besides many other processes, possible via its formation of ATP.

Comparison of the processes, represented by the proteins of the second and third uprise, shows similarities and differences. For instance: protein synthesis via ribosomes at the ER counts for $50 \%$ in uprise 3, but only for half as much (26\%) in uprise 2 . Uprise 2 covers transcription regulation, DNA repair and replication + chromosome stabilisation (1 item), whereas uprise 3 does not. Protein folding at ER (1 item) occurs in both periods, but cargo sorting at the plasma membrane and trans-Golgi network (2 items) is only in period 2. The same holds for recycling from Golgi $\rightarrow$ ER (1 item), whereas protein transport across the ER (1 item) belongs only to period 3 . On the other hand, protein cleavage (either by proteasome subunit $\alpha$ type- 7 or trypsin) occurs in both periods. The same holds true for actin tracks ( 2 and 1 item, respectively), but not for actin linkers ( 3 in period 2 only). Both periods contain vesicle transport ( 1 and 2 items in periods 2 and 3 , respectively). Further activities that relate only to period 2 are protein shape conservation + cytoskeletal stabilisation + signal transduction by heat-shock proteins (2 items). Activities that are related to closing and opening the valves, plus the enzyme that this facilitates (ATP synthase) (3 items), only occur in the second uprise, but cellular signalling by Rab-1b and enzymes involved in the hydrolysis of polysaccharides are confined to uprise 3 (4 items).

\section{Discussion}

Table 1 showed an abundance of $52 \%$ in bacterial ribosomal subunits. Although the presence of bacteria in the intestine of a eucaryote is a common phenomenon, the capacity of the present bacteria to break down and thereby detoxicate organic pollutants raises the possibility that these bacteria have been added on purpose to the canal inhabited by the mussel. The following detoxifying properties have been ascribed to some of the indicated strains: P. fluorescens is beneficial for plants in terms of suppressing pathogens, aiding nutrient absorption 
and degrading environmental pollutants (www.buzzle. com/articles/pseudomonas-fluorescens.html). P. putida is a versatile environmental isolate that is capable of growth on several aromatic hydrocarbons, including benzene, toluene, ethylbenzene and p-cymene. Its broad substrate toluene dioxygenase has been widely utilised in biocatalytic synthesis of chiral chemicals, as well as in the metabolism and detoxification of trichloroethylene (TCE). P. putida F1 is known to be chemotactic to aromatic hydrocarbons and chlorinated aliphatic compounds and has the potential for use in biomediation applications (genome.jgi-psf.org/psepu/psepu.home.html) (site of DOE Joint Genome Institute, University of California). On the other hand, the strain W619 that showed up in our analyses is more competent with regard to heavy metal resistances and beneficial effects on plants (Wu et al. 2011).

P. mendocina DSWY0601 and ymp extrude a polyhydroxybutyrate (PHB) depolymerase that can degrade PHB plastic (Yan et al. 2012). P. stutzeri strain A1501 is equally beneficial to plants by denitrification of $\mathrm{NO}_{3}^{-}$, converting it to $\mathrm{N}_{2}$ and fixation of $\mathrm{N}_{2} \rightarrow 2 \mathrm{NH}_{3}$. Subsequently, $\mathrm{NH}_{4}^{+}$is coupled to $\alpha$-ketoglutarate under formation of glutamate (Stryer 1995c; Lalucat et al. 2006).

In contrast to the above positive descriptions, the list of bacteria also contains some negatively acting contributors: $P$. aeruginosa, $P$. syringae and $E$. coli. P. aeruginosa, despite its positive contribution in oil degradation in the presence of glycerol or the biosurfactant rhamnolipid (Zhang et al. 2005b), also excretes toxins that are deleterious for the pulmonary system (Roy-Burman et al. 2001). P. syringae is a plant-pathogenic bacterium, infecting bean to tomato, causing bacterial speck to bacterial cancer ( $P$. syringae Genome Resources home page: Pseudomonas-Plant Interaction (PPI) from Cornell University: Department of Plant Pathology: www. pseudomonas-syringae.org). E. coli APEC01 is a deleterious avian pathogenic bacterium causing epidemic colibacillosis in the poultry industry (Kabir 2010).

Some data of similarity with C. anguineus (Schuurmans Stekhoven et al. 2012) are: synaptic vesicle traffic (Ngsee et al. 1991) and enolase in the plasma membrane of synaptosomes (Ueta et al. 2004). The first reminded us of the neurotransmitter cycle that we found in the brain of $C$. anguineus via its modulator $\alpha$-synuclein and $\mathrm{v}$ - and $\mathrm{t}$ snares VAMP1/2 and SNAP-25 + syntaxin 1. However, although bivalves contain a nervous system (Encyclopaedia Brittanica: www.brittannica.com/EBchecked/topic/67293/ bivalve/35745/The-shell), we have not been able to find the abovementioned $\mathrm{v}$ - or $\mathrm{t}$-snares for bivalves. In partial contrast to this are the results obtained for M. galloprovincialis (Venier et al. 2009) in which results for three t-snares in the Mediterranean mussel have been obtained via transcribed sequences: SNAP-25A [Accession No. Q5TZ66], SNAP-type protein [Accession No. Q25391] and SNAP-47
[Accession No. Q0P4A7]. Yet, v-snares have not been detected either in this case. Presence of enolase in the plasma membrane appears to have an endangering effect via its complex formation with plasminogen that by subsequent activation to plasmin can break down the extracellular matrix and so can allow invasion of pathogens, viruses and metastatic cancer cells (Liu and Shih 2007; Díaz-Ramos et al. 2012). Normally, plasmin is used to dissolve fibrin blood clots but upon generation on the cell surface might cause the above effects. However, in our analyses, neither plasminogen nor plasmin (MW 81 and 75.4 kDa, Barlow et al. 1969) or plasminogen activator (tPA, MW $72 \mathrm{kDa}$, Manosroi et al. 2001) has been traced. On the other hand, in the transcribed sequences of M. galloprovincialis, two sequences were found that matched plasminogen [Accession No's. Q01177 and Q6PBA6] (Venier et al. 2009). Furthermore, despite the clear presence of $\mathrm{Na}^{+} / \mathrm{K}^{+}$-ATPase in our analyses, we have been unable to find the presence of phospholemman (FXYD1), known as a modulator of $\mathrm{Na}^{+} / \mathrm{K}^{+}$-ATPase (Mahmmoud et al. 2000), even though our analyses covered a wide range of molecular weights (14.1 to $240 \mathrm{kDa}$ ). Since phosphorylation of $\mathrm{Na}^{+} / \mathrm{K}^{+}$-ATPase causes dissociation of phospholemman, this may have led to its absence in the analyses. In addition, salinity may also decrease the FXYD content relative to the $\mathrm{Na}^{+} / \mathrm{K}^{+}$-ATPase content (Wang et al. 2008). In another report (Horisberger 2006), it has been indicated that no FXYD protein can be found in arthropods or any nonvertebrate animals. We think that the only way that is left to trace the absence or presence of FXYD in bivalves is to analyse their DNA.

One of the fungi that have entered the list of comparative sequences is P. graminis at actin in Table 3. This mould spreads its occurrence by spore formation via two different hosts, thereby causing the so-called stemrust, especially in wheat and barley (Schumann and Leonard 2000). Although contamination of the brackish water mussel with infected wheat and/or barley from freight ships in the harbour cannot be excluded, another possibility is indistinguishable peptides formed by trypsin treatment (cf. Schuurmans Stekhoven et al. 2010) as used in the analysis of actin from Crassostrea gigas [Accession No. O17320] or Puccinia graminis [Accession No. P50138]. A few of the possibilities are ${ }^{20}$ gfagddapr $^{29}$, $\mathrm{h}^{41}$ qgvmvgmgqk $^{51}$ and $\mathrm{y}^{70}$ piehgivtnwddmek ${ }^{85}$ for Crassostrea gigas and the same sequences for Puccinia graminis, but with a numbering of $\mathrm{a}^{19}-\mathrm{r}^{28}, \mathrm{~h}^{40}-\mathrm{k}^{50}$ and $\mathrm{y}^{69}-\mathrm{k}^{84}$. It appears that the sequences are quite conserved since they are also found in $\beta$-actin of the mammal M. musculus [Accession No. ABL01512].

Another subject of criticism is the possibly hereditary plant sequences in the genome of the mussel. An example could be the occurrence of Proteasome subunit $\alpha$ 
type-5A and ADP/ATP carrier protein from Arabidopsis thaliana (thale cress). Thale cress grows on edges of agricultural fields, stone walls alongside tracks and roads and Mediterranean scrublands with scattered holm oaks but is no inhabitant of wet lands (Picó et al. 2008). Therefore, we have looked for comparable sequences in MytiBase: a knowledgebase of mussel (M. galloprovincialis) with 3,275 transcribed sequences (Venier et al. 2009). To our surprise: also in this large list of transcribed proteins, a few examples of plant heritage were met: first the occurrence of 14-3-3-like protein b of Oryza sativa (India Group) [Accession No. ABR25888] together with 14-3-3 C1 protein from Oncorhynchus mykiss [Accession No. Q6UFZ7]. Identical sequences, found for Oryza sativa with those for $O$. mykiss (the latter between parentheses), are $\mathrm{e}^{16}-\mathrm{e}^{34}\left(\mathrm{e}^{113}-\mathrm{e}^{131}\right), \mathrm{p}^{65}-\mathrm{f}^{80}\left(\mathrm{p}^{162}-\mathrm{f}^{177}\right), \mathrm{l}^{94}-\mathrm{d}^{100}\left(\mathrm{l}^{191}-\mathrm{d}^{197}\right)$ and $\mathrm{s}^{113}-\mathrm{d}^{134}\left(\mathrm{~s}^{210}-\mathrm{d}^{231}\right)$. It is evident that the sequence for Oryza sativa is 97 amino acids less than that of O. mykiss, due to incomplete DNA. Yet, we can calculate an identity that must be minimally $25 \%$ the same. Since the sequences in case of M. galloprovincialis have been determined via DNA, we have to accept a genetic link between animals and plants, and so the link with proteasome subunit $\alpha$ type 5A, ADP/ATP carrier protein 3 and Arabidopsis thaliana may be genuine and not artificial.

A second example of plant heritage by M. galloprovincialis is found in the presence of probable ATPase from the chloroplast of Oenothera organensis (organ Mountains evening primrose) [Accession No. Q0H0T1] which grows in the mountains of New Mexico, far away from the mussel of the Mediterranean Sea. Hence, there has been a time that they were neighbours. This hypothesis is built on three assumptions:

1. Some DNA of consumed food can be taken up in cells and incorporated into the DNA of the consumer if it displays some similarity with DNA of that consumer.

2. Since bivalves do not inhabit the mainland, the plant consumers could be snails (Gastropods), which form a sister clade with bivalves, forming the Pleistomollusca (Kokot et al. 2011).

3. If geological conditions, like flooding, would force gastropods to evolve to bivalves, it is not unthinkable that bivalves would contain land plant sequences in their genome as has been shown by Venier et al. (2009). Before accepting this hypothesis, it will be necessary to trace the snail's genome or RNA for plant resemblances.

In the generation of the brackish water mussel M. leucophaeata in the period of 1,070 to 0 MYA, two additional genetic uprises occurred beyond the uprise caused by the generation of the bivalves per se (approximately 510 MYA). The question arises why this has to be achieved by acceleration in a developmental uprise: the second in the period of 48 to 4.75 MYA and the third in the period of 1.4 to 0 MYA. In the 48 to 4.75 MYA period (Eocene-Pliocene), earth was in motion with formation of mountains and separation or collision of geological plates, volcano formation, followed by climate cooling (Pidwirny 2012). In the later period (1.4 to 0 MYA: Pleistocene + Holocene), earth was subject to freezing (Pleistocene Ice Age) with extinction of many species (Pidwirny 2012), which may have forced the mussel to a counterreaction by speeding up its adaptation of DNA to that of modern species (cow, chimpanzee, human, dog, stemrust and wild boar, Table 5).

Evidence for climate change-induced effects on adaptation of the genome of animals and plants has been recently published (Reusch and Wood 2007; Buckley et al. 2012; Franks and Hoffmann 2012). Failure to adapt to the changes may eventually lead to extinction. In this respect, $M$. leucophaeata did not fail, otherwise it could not have been able to survive for 500 million years until present (Figure 2). Therefore, it is remarkable that it has only a limited range of salt concentration: 6.7 to $7.4 \mathrm{ppt}$ $(\%$ oo $)$ to provide for an optimal condition. At higher salinities, the condition index is reduced to 50 at a salinity of 11 ppt (Grutters and Verhofstad 2010). Seawater usually has a salinity of 35 ppt (Office of Naval Research: www.onr.navy.mil/focus/ocean/water/salinity 1.htm). Therefore, one may question how M. leucophaeata can survive the trip via the ocean to the brackish North Sea Channel. Transportation of larvae and postlarvae with tolerance to salinity of $32 \mathrm{ppt}$ in ballast water makes the trip possible (Verween et al. 2010). The salinity of the North Sea Channel varies from 1.7 to $9.2 \mathrm{ppt}$ (Van der Velde et al. 1998), which M. leucophaeata can enter with confidence.

\section{Competing interests}

The authors declare that they have no competing interests.

\section{Authors' contributions}

FSS carried out the homogenisation and fractional centrifugation of the bivalve homogenate, electrophoresis of the fractions, staining and destaining of the gels and conveying the gel strips to the analytical laboratory of ARB in Leicester. Further, he interpreted the data and wrote this article. THL offered his contribution in formatting of the text and provided his data (included in this paper) on the effect of salinity change on the expression of FXYD, a modulator of $\mathrm{Na}^{+} / \mathrm{K}^{+}$-ATPase. GvdV, the malacologist of our department, provided essential information on the anatomy and physiology of mollusks, and ARB, together with Lady S. Ibrahim, analysed the gel strips and sent me the proteomic data together with their accession numbers in the data banks. All authors read and approved the final manuscript.

\section{Acknowledgements}

We like to thank M.Sc. Michiel Verhofstad and M.Sc. Bart Grutters for their gift of M. leucophaeata, which is at the basis of this study. As in my previous publication (Schuurmans Stekhoven et al. 2012), M.Sc. Ruud van Hintum helped me by photography of the gels after electrophoresis of the F1 to F3 fractions. Also, K. van Benthem is acknowledged for the construction of Figure 1 of this paper and my son M.G.H.P. Schuurmans Stekhoven for the construction of Figure 2, Lady S. Ibrahim (Protein and Nucleic Acid Chemistry Laboratory, Proteomics Facility), University of Leicester for her contribution in the protein analyses of this paper and of course Kiki Wu for her textual settings. 


\section{Author details}

'Department of Animal Ecology and Ecophysiology, Faculty of Science, Radboud University Nijmegen, Heyendaalseweg 135, 6525 AJ Nijmegen, The Netherlands. 'Department of Life Sciences, National Chung-Hsing University, Taichung 402, Taiwan. ${ }^{3}$ Protein and Nucleic Acid Chemistry Laboratory, Proteomics Facility, University of Leicester, Lancaster Road, Leicester LE1 9HN, UK. ${ }^{4}$ Naturalis Biodiversity Center, P.O. Box 9517,2300RA Leiden, The Netherlands.

Received: 9 May 2014 Accepted: 10 December 2014

Published online: 23 January 2015

\section{References}

Awasthi A, Samarakoon A, Chu H, Kamalakannan R, Quiliam LA, ChrzanowskaWodnicka M, White GC II, Malarkannan S (2010) Rap-1b facilitates NK cell functions via IQGAP1-mediated signalosomes. J Exp Med 207:1923-1938

Bagley N (2013) Cambrian Period: Facts \& Information. www.livescience.com/ 28098-cambrian-period.html

Barlow GH, Summaria L, Robbins KC (1969) Molecular weight studies on human plasminogen and plasmin at the microgram level. J Biol Chem 244:1138-1141

Baxeranis AD, Kappas I, Abatzopoulos TJ (2006) Molecular phylogenetics and asexuality in the brine shrimp Artemia. Mol Phyl Evol 40:724-738

Berger W, Steiner E, Grusch M, Elbling L, Micksche M (2009) Vaults and the major vault protein: novel roles in signal pathway regulation and immunity. Cell Mol Life Sci 66:43-61

Branco M, Ferrand N, Monnerot M (2000) Phylogeography of the European rabbit (Orectolagus cuniculus) in the Iberian Peninsula inferred from RFLP analysis of the cytochrome b gene. Heredity 85:307-317

Buckley J, Butlin RK, Bridle JR (2012) Evidence for evolutionary change associated with the recent range expansion of the British butterfly, Aricia agestis, in response to climate change. Mol Ecol 21:267-280

Cambiazo V, González M, Isamit C, Maceoni RB (1999) The $\beta$-isoform of heat shock protein hsp-90 is structurally related with human microtubule-interacting protein Mip-90. FEBS Lett 457:343-347

Cartwright P, Halgedahl SL, Hendricks JR, Jarrad RD, Marques AC, Collins AG, Lieberman BS (2007) Exceptionally preserved jellyfishes from the Middle Cambrian. PLoS One 2(10):e1121

Chavrier P, Goud B (1999) The role of ARF and Rab GTPases in membrane transport. Curr Opin Cell Biol 11:466-475

D'Souza-Schorey C, Chavrier P (2006) ARF proteins: roles in membrane traffic and beyond. Nature Rev Cell Biol 7:347-358

Danis P, Farkas R (2009) Hormone-dependent and hormone-independent control of metabolic and developmental functions of malate dehydrogenase. Review Endocrine Reg 43:39-52

De Maio A (1999) Heat shock proteins: facts, thoughts, and dreams. Shock $11: 1-12$

Díaz-Ramos À, Roig-Borellas A, Garcia-Melero A, López-Alemany R (2012) a-Enolase a multifunctional protein: its role on pathophysiological situations. J Biomed Biotech doi:10.1155/2012/156795

Djinovic-Carugo K, Gautel M, Ylänne J, Young P (2002) The spectrin repeat: a structural platform for cytoskeletal assemblies. FEBS Lett 513:119-123

Dugina V, Zwaenepoel I, Gabbiani G, Clément S, Chaponnier C (2009) $\beta$-and $\gamma$-cytoplasmic actins display distinct distribution and functional diversity. J Cell Sci 122:2980-2988

Feng C, Li Y-F, Yan Y-H, Lee H-S, Tang X-Y, Xue Z-H, Zhou Y-C, Lim W-M, Cornvik TC, Ruedl C, Schochat SG, Tan S-M (2012) Kindlin-3 mediates integrin aL $\beta 2$ outside-in signaling, and it interacts with scaffold protein receptor for activated-c kinase 1 (Rack1). J Biol Chem 287:10714-10726

Fields PA, Zuzow MJ, Tomanek L (2012) Proteomic responses of blue mussel (Mytilus) congeners to temperature acclimation. J Exp Biol 215:1106-1116

Franks SJ, Hoffmann AA (2012) Genetics of climate change adaptation. Ann Rev Genet 46:185-208

Furano AV, Usdin K (1995) DNA "fossils" and phylogenetic analysis, using L1 (Line-1, long interspersed repeated) DNA to determine the evolutionary history of mammals. J Biol Chem 270:25301-25304

Germonpré M, Sablin MV, Stevens RE, Hedges REM, Hofreiter M, Stiller M, Després VR (2009) Fossil dogs and wolves from Paleolithic sites in Belgium, the Ukraine and Russia: ostometry, ancient DNA and stable isotopes. J Archaeol Sci 36:473-490
Geuze JJ, Slot JW, Tokuyasu KT, Goedemans WEM, Griffith JM (1979) Immunochemical localization of amylase and chymotrypsinogen in the exocrine pancreatic cell with special attention to the Golgi complex. J Cell Biol 82:697-707

Gietl C (1992) Malate dehydrogenase isoenzymes: cellular locations and role in the flow of metabolites between the cytoplasm and cell organelles. Biochim Biophys Acta 1100:217-234

Grimaldi D, Engel MS (2005) Evolution of the insects, Part of Cambridge Evolution Series. Cambridge University Press, Cambridge

Grutters BMC, Verhofstad MJJM (2010) Assessing and comparing three invasive bivalves: Dreissena polymorpha, Dreissena rostriformis bugensis and Mytilopsis leucophaeata. Master thesis Department of Ecology and Ecophysiology, Radboud University, Nijmegen

Hanss B, Leal-Pinto E, Teixeira A, Christian RE, Shabanowitz J, Hunt DF, Klotman PE (2002) Cytosolic malate dehydrogenase confers selectivity of the nucleic acid conducting channel. Proc Natl Acad Sci U S A 99:1707-1712

Hardjasasmita HS (1987) Taxonomy and phylogeny of the Suidae (Mammalia) in Indonesia. Scripta Geol 85:1-68

Hartwig JH, Chambers KA, Stossel TP (1989) Association of gelsolin with actin filaments and cell membranes of macrophages and platelets. J Cell Biol 108:467-479

Hedges SB (2002) The origin and evolution of model organisms. Nat Rev Genet 3:838-849

Hegde AN (2010) The ubiquitin-proteasome pathway and synaptic plasticity. Learn Mem 17:314-327

Hicke L, Dunn R (2003) Regulation of membrane protein transport by ubiquitin and ubiquitin-binding protein. Ann Rev Cell Dev Biol 19:141-172

Hofler C, Koelle MR (2011) AGS-3 alters Caenorhabditis elegans behavior after food deprivation via Ric-8 activation of the neural $G$ protein $\mathrm{Ga}_{0}$. J Neurosci 31:11553-11562

Horisberger J-D (2006) Evolution of Na-K-ATPases. Plenary Lecture LT_1.02. 99, Annual Meeting of the German Zoological Society, September. $\mathbf{1 6}-20$. Abstractband, Münster, p 9

Huvet A, Daniel J-Y, Quéré C, Dubois S, Prudence M, van Wormhoudt A, Sellos D, Samain J-F, Moal J (2003) Tissue expression of two a-amylase genes in the pacific oyster Crassostrea gigas: Effects of two different food rations. Aquaculture 228:321-333

Irannejad R, Wedegaertner PB (2010) Regulation of constitutive cargo transport from the trans-Golgi network to plasma membrane by Golgi-localized $G$ protein $\beta$ y subunits. J Biol Chem 285:32393-32404

Kabir SML (2010) Avian colibacillosis and salmonellosis: a closer look at epidemiology, pathogenesis, diagnosis, control and public health concerns. Int J Environ Res Public Health 7:89-114

Kansas Geological Survey (2005) www.kgs.ku.edu/Extension/fossils/gastropod. html

Kansas Geological Survey (2008) www.kgs.ku.edu/Extension/fossils/bivalve.html

Kislev ME (1982) Stem rust of wheat 3300 years old found in Israel. Science 216:993-994

Kokot KM, Cannon JT, Todt C, Citarella MR, Kohn AB, Meyer A, Santos SR, Schander C, Moroz LL, Lieb B, Halanych KM (2011) Phylogenomics reveals deep molluscan relationships. Nature 477:452-457

Lacabaratz-Porret C, Corvazier E, Kovàcs T, Bobe R, Bredoux R, Launay S, Papp B, Enouf J (1998) Platelet sarco/endoplasmatic reticulum $\mathrm{Ca}^{2+}$ ATPase isoform $3 \mathrm{~b}$ and rap $1 \mathrm{~b}$ : interaction and regulation in physiopathology. Biochem J 332:173-181

Lalucat J, Bennasar A, Bosch R, Garcia-Valdés E, Palleroni NJ (2006) Biology of Pseudomonas stutzeri. Microbiol Mol Biol Rev 70(2):510-547

Liu K-J, Shih N-Y (2007) The role of enolase in tissue invasion and metastasis of pathogens and tumor cells. J Cancer Mol 3:45-48

Liu G, Tang J, Edmonds BT, Murray J, Levin S, Condeels J (1996) F-actin sequesters elongation factor 1 a from interaction with aminoacyl-tRNA in a $\mathrm{pH}$-dependent reaction. J Cell Biol 135:953-963

Mac Hugh DE, Shriver MD, Loftus RT, Cunningham P, Bradley DG (1997) Microsatellite DNA variation and the evolution, domestication and phylogeography of Taurine and Zebu cattle (Bos taurus and Bos indicus). Genetics 146:1071-1086

Mahmmoud YA, Vorum H, Cornelius F (2000) Identification of a phospholemman-like protein from shark rectal glands. Evidence for indirect regulation of $\mathrm{Na}$, K-ATPase by protein kinase $\mathrm{C}$ via a novel member of the FXYD family. J Biol Chem 275:35969-35977 
Manosroi J, Tayapiwatana C, Götz F, Werner RG, Manosroi A (2001) Secretion of active recombinant human tissue plasminogen activator derivatives in Escherichia coli. Appl Environ Microbiol 67:2657-2664

Margolis RN, Cardell RR, Curnow RT (1979) Association of glycogen synthase phosphatase and phosphorylase phosphatase activities with membranes of hepatic smooth endoplasmic reticulum. J Cell Biol 83:348-356

Marridonneau-Parini I, de Gunzburg J (1992) Association of rap1 and rap2 proteins with the specific granules of human neutrophils: translocation to the plasma membrane during cell activation. J Biol Chem 267:6396-6402

Marshansky V, Futai M (2008) The V-type $\mathrm{H}^{+}$-ATPase in vesicular trafficking: targeting, regulation and function. Curr Opin Cell Biol 20:415-426

Mlikovský J (1989) A new guinea fowl (Aves, Phasianidae) from the late Eocene of France. Ann Naturhist Mus Wien 90A:63-66

Mollinedo F, Perez-Sala D, Gajate C, Jimenez B, Rodriguez P, Lacal JC (1993) Localization of rap1 and rap2 proteins in the gelatinase-containing granules of human neutrophils. FEBS Lett 326:209-214

Murti KG, Smith HT, Fried VA (1988) Ubiquitin is a component of the microtubule network. Proc Natl Acad Sci U S A 85:3019-3023

Napolitano A, de Lucia M, Panzella L, d'Ischia M (2008) The "benzothiazine" chromophore of pheomelanins: a reassessment. Photochem Photobiol 84:593-599

Ngsee JK, Elferink LA, Scheller RH (1991) A family of ras-like GTP-binding proteins expressed in electromotor neurons. J Biol Chem 266:2675-2680

Nyitray L, Goodwin EB, Szent-Györgyi AG (1991) Complete primary structure of a scallop striated muscle myosin heavy chain. Sequence comparison with other heavy chains reveals regions that might be critical for regulation. J Biol Chem 266:18469-18476

Nylandsted J, Gyrd-Hansen M, Danielewicz A, Fehrenbacher N, Lademann U, Høyer-Hansen M, Weber E, Multhoff G, Rohde M, Jäättelä M (2004) Heat shock protein 70 promotes cell survival by inhibiting lysosomal membrane permeabilization. J Exp Med 200:425-435

Obsil T, Obsilova V (2011) Structural basis of 14-3-3 protein functions. Semin. Cell Dev Biol doi:10.1016/j.semcdb. 2011.09.001

Oklahoma State University, Department of Animal Science (Ansi): (www.ansi.okstate. edu/breeds/goats/)

Picó FX, Méndez-Vigo B, Martínez-Zapater JM, Alonso-Blanco C (2008) Natural genetic variation of Arabidopsis thaliana is geographically structured in the Iberian Peninsula. Genetics 180:1009-1021

Pidwirny M (2012) Geologic time, The Encyclopedia of Earth. Educational site of the Environmental Information Coalition (EIC), Washington D.C, www.eoearth.org

Pollard TD, Cooper JA (2009) Actin, a central player in cell shape and movement. Science 326:1208-1212

Pre-Historic Sharks (2012) About prehistoric Sharks-Megalodon, fossil teeth, (http://www.sharkattacks.com/prehistoric.htm)

Reid GBR, Hetherington R (2010) The climate connection: climate change and human evolution. Cambridge University Press, Cambridge, UK, p64.ISBN 0-521-14723-9

Reusch TBH, Wood TE (2007) Molecular ecology of global change. Mol Ecol 16:3973-3992

Riva C, Cristoni S, Binelli A (2012) Effects of triclosan in the freshwater mussel Dreissena polymorpha: a proteomic investigation. Aquatic toxicol 118-119:62-71

Robinson MS, Bonifacino JS (2001) Adapter-related proteins. Curr Opin Cell Biol 13:444-453

Rowling PJE, McLaughlin SH, Pollock GS, Freedman RB (1994) A single purification procedure for the major resident proteins of the ER lumen: endoplasmin, BIP, calreticulin and protein disulfide isomerase. Prot Expr Purif $5: 331-336$

Roy-Burman A, Savel RH, Racine S, Swanson BL, Revadigar NS, Fujimoto J, Sawa T, Frank DW, Wiener-Kronish JP (2001) Type III protein secretion is associated with death in lower respiratory and systemic Pseudomonas aeruginosa infections. J Inf Dis 183:1767-1774

Sahyoun N, McDonald OB, Farrell F, Lapetina EG (1991) Phosphorylation of Ras-related GTP-binding protein, Rap-1b, by a neuronal $\mathrm{Ca}^{2+} /$ calmodulindependent protein kinase, CaM kinase Gr. Proc Natl Acad Sci U S A 88:2643-2647

Schumann GL, Leonard KJ (2000) Stem Rust of Wheat (black rust). The Plant Health Instructor. doi:10.1094/PHI-I-2000-0721-01

Schuurmans Stekhoven FMAH, Grell E, Atsma W, Flik G, Wendelaar Bonga SE (2003) Organ-related distribution of phospholemman in the spiny dogfish Squalus acanthias. Biochem Biophys Res Commun 303:1008-1011
Schuurmans Stekhoven FMAH, Wendelaar Bonga SE, Flik G (2004) Extranuclear histones in teleost gills: an evolutionary study. Fish. Physiol Biochem 30:201-211

Schuurmans Stekhoven FMAH, Wendelaar Bonga SE, Lee T-H, Bottrill AR (2010) Presence or absence of the $\mathrm{Cl}^{-}$channel phospholemman in the rectal gland of sharks: a comparative study. Zool Studies 49:326-334

Schuurmans Stekhoven FMAH, Lee T-H, Wang P-J, Jang-Liaw N-H, Tanaka S, Bottrill AR (2012) Proteomic studies of various organs and tissues of the frilled shark Chlamydoselachus anguineus. Zool Studies 51:1248-1269

Seo J-K, Stephenson J, Noga EJ (2011) Multiple antibacterial histone H2B proteins are expressed in tissues of American oyster. Comp Biochem Physiol B 158:223-229

Smith AB (1984) Echinoid Palaeobiology in Special Topics in Palaeontology 1. Allen \& Unwin, London

Souès S, Kann M-L, Fouquet J-P, Melki R (2003) The cytosolic chaperonin CCT associates to cytoplasmic microtubular structures during mammalian spermiogenesis and to heterochromatin in germline and somatic cells. Exp Cell Res 288:363-373

Sreedhar AS, Kalmár E, Csermely P, Shen Y-F (2004) Hsp90 isoforms: functions, expression and clinical importance. FEBS Lett 562:11-15

Stryer $L$ (1995a) The Power Stroke in Contraction is Driven by Conformational Changes in the Myosin S1 Head, 4th edn. Biochemistry, WH Freeman and Company, NY, pp 399-400

Stryer L (1995b) Phosphoenolpyruvate Carboxykinase, 4th edn. Biochemistry, WH Freeman and Company, NY, p 571

Stryer L (1995c) Nitrogen Fixation: Microorganisms Use ATP and a Powerful Reductant to Reduce $\mathrm{N}_{2}$ to $\mathrm{NH}_{3}$, 4th edn. Biochemistry, WH Freeman and Company, NY, pp 714-717

Takehana Y, Nagai N, Matsuda M, Tsuchiya K, Sakaizumi M (2003) Geographic variation and diversity of the cytochrome $b$ gene in Japanese wild populations of Medaka, Orizias latipes. Zool Sci 20:1279-1291

Takeuchi T, Harris JL, Huang W, Yan KW, Coughlin SR, Craik CS (2000) Cellular localization of membrane-type serine protease 1 and identification of protease-activated receptor- 2 and single-chain urokinase-type plasminogen activator as substrates. J Biol Chem 275:26333-26342

Tata JR (1964) Subcellular redistribution of liver a-glucan phosphorylase during alterations in glycogen content. Biochem J 90:284-292

Tisdale EJ, Azizi F, Artalejo CR (2009) Rab 2 utilizes glyceraldehyde-3-phosphate dehydrogenase and protein kinase $\mathrm{Ci}$ to associate with microtubules and to recruit dynein. J Biol Chem 284:5876-5884

Tomanek L, Zuzow MJ (2010) The proteomic response of the mussel congeners Mytilus galloprovincialis and M. trossulus to acute heat stress: implications for thermal tolerance limits and metabolic costs of thermal stress. J Exp Biol 213:3559-3574

Tomanek L, Zuzow MJ, Hitt L, Serafini L, Valenzuela JJ (2012) Proteomics of hyposaline stress in blue mussel congeners (genus Mytilus): implications for biogeographic range limits in response to climate change. J Exp Biol doi:10.1242/jeb.076448

Ueta H, Nagasawa H, Oyabu-Manabe Y, Toida K, Ishimura K, Hori H (2004) Localisation of enolase in synaptic plasma membrane as an ay heterodimer in rat brain. Neurosc Res 48:379-386

Valderrama F, Therapala S, Ridley AJ (2012) Radixin regulates cell migration and cell-cell adhesion through Rac 1. J Cell Sci 125:3310-3319

Van der Velde G, van der Gaag M, Rajagopal S, Jenner HA (1998) Where do the exotic mussels Dreissena polymorpha and Mytilopsis leucophaeata meet in the brackish Noordzeekanaal, The Netherlands? In: 8th International Zebra Mussel and Other Aquatic Nuisance Species Conference, 16-19 March 1998, Sacramento, USA, p. 54

Venier P, de Pittà C, Bernante F, Varotto L, de Nardi B, Bovo G, Roch P, Novoa B, Figueras A, Pallavicini A, Lanfranchi G (2009) MytiBase: a knowledge base of mussel (M. galloprovincialis) transcribed sequences. BMC Genomics 10:72, doi:10.1186/1471-2164-10-72

Verneau O, Catzeflis F, Furano AV (1998) Determining and dating recent rodent speciation events by using L1 (Line-1) retrotransposons. Proc Natl Acad Sci U S A 95:11284-11289

Verween A, Vincx M, Degraer S (2010) Mytilopsis leucophaeata: the brackish water equivalent of Dreissena polymorpha? A review. In: Van der Velde G, Rajagopal S, Bij de Vaate A (eds) The zebra mussel in Europe. Backhuys Publishers, Leiden/ Margraf Publishers, Weikersheim, pp 29-44

Veyrunes F, Dobigny G, Yang F, O'Brien PCM, Catalan J, Robinson TJ, Britton-Davidian J (2006) Phylogenomics of the genus Mus (Rodentia, Muridae): extensive genome repatterning is not restricted to the house mouse. Proc R Soc B 273:2925-2934 
Volff J-N (2005) Genome evolution and biodiversity in teleost fish. Heredity 94:280-294 Waggoner BM (2000) Anthozoa: Fossil Record. http://www.ucmp.berkeley.edu/ cnidaria/anthozoafr.html

Wang P, Heitman J (2005) The cyclophilins. Genome Biol 6:226

Wang $X$, Junbing L, Shunping $H$ (2007) Molecular evidence for the monophyly of East Asian groups of Cyprinidae (Teleostei, Cypriniformes) derived from the nuclear recombination activating gene 2 sequences. Mol Phyl Evol 42:157-170

Wang P-J, Lin C-H, Hwang H-H, Lee T-H (2008) Branchial FXYD protein expression in response to salinity change and its interaction with $\mathrm{Na}^{+} / \mathrm{K}^{+}$-ATPase of the euryhaline teleost Tetraodon nigroviridis. J Exp Biol 211:3750-3758

Wegener Parfrey L, Lahr DJG, Knoll AH, Katz LA (2011) Estimating the time of early eukaryotic diversification with multigene molecular clocks. Proceed Natl Acad Sci USA doi:10.1073/pnas.1110633108

Willett M, Pollard HJ, Vlasak M, Morley SJ (2010) Localization of ribosomes and translation initiation factors to talin/ $\beta 3$-integrin-enriched adhesion complexes in spreading and migrating mammalian cells. Biol Cell 102:265-276

Won YJ, Hey J (2005) Divergence population genetics of chimpanzees. Mol Bio Evol 22:297-307

Wood RR (2011) Analysis of bacterial communities in the eastern oyster (Crassostrea virginica) with emphasis on Vibrio vulnicus dynamics under refrigeration. PhD thesis. Auburn University, Alabama

Wu X, Monchy S, Taghavi S, Zhu W, Ramos J, van der Lelie D (2011) Comparative genomics and functional analysis of niche-specific adaptation in Pseudomonas putida. FEMS Microbiol Rev 35:299-323

Yam AY, Xia Y, Lin H-TJ, Burlingame A, Gerstein M, Frydman J (2008) Defining the TRIC/CCT interactome links chaperonin function to stabilization of newly-made proteins with complex topologies. Nat Struct Mol Biol 15:1255-1262

Yan C, Sato M, Lanier SM, Smrcka AV (2007) Signaling by a non-dissociated complex of $G$ protein $\beta \gamma$ and a subunits stimulated by a receptor-independent activator of G protein signaling AGS8. J Biol Chem 282:19938-19947

Yan W, Fan L, Zhan-Yong W, Dong-Bo L, Hong-Mei X, Ling-Fei L, Shan C (2012) Purification and properties of an extracellular polyhydroxybutyrate depolimerase from Pseudomonas mendocina DSWY0601. Chem Res Chin Univ 28(3):459-464

Zhang P, Zhou H, Chen Y-Q, Liu Y-F, Qu L (2005a) Mitogenomic perspectives of the origin and phylogeny of living amphibians. Syst Biol 54:391-400

Zhang G-L, Wu Y-T, Qian X-P, Meng Q (2005b) Biodegradation of crude oil by Pseudomonas aeruginosa in the presence of rhamnolipids. J Zhejiang Univ (Sci) 6B(8):725-730

Ziegler ME, Souda P, Jin Y-P, Whitelegge JP, Reed EF (2012) Characterization of the endothelial cell cytoskeleton following HLA class I ligation. Plos ONE 7(1):e29472

\section{Submit your manuscript to a SpringerOpen ${ }^{\circ}$ journal and benefit from:}

- Convenient online submission

- Rigorous peer review

- Immediate publication on acceptance

- Open access: articles freely available online

- High visibility within the field

- Retaining the copyright to your article

Submit your next manuscript at $>$ springeropen.com 